\title{
Technlogy indicators: poplution, labour and schooling
}

Citation for published version (APA):

Ramaekers, G. W. M., \& Hoevenberg, J. (1994). Technlogy indicators: poplution, labour and schooling. Researchcentrum voor Onderwijs en Arbeidsmarkt, Faculteit der Economische Wetenschappen. ROA Reports No. 2E https://doi.org/10.26481/umarep.199402E

Document status and date:

Published: 01/01/1994

DOI:

10.26481/umarep.199402E

Document Version:

Publisher's PDF, also known as Version of record

\section{Please check the document version of this publication:}

- A submitted manuscript is the version of the article upon submission and before peer-review. There can be important differences between the submitted version and the official published version of record.

People interested in the research are advised to contact the author for the final version of the publication, or visit the DOI to the publisher's website.

- The final author version and the galley proof are versions of the publication after peer review.

- The final published version features the final layout of the paper including the volume, issue and page numbers.

Link to publication

\footnotetext{
General rights rights.

- You may freely distribute the URL identifying the publication in the public portal. please follow below link for the End User Agreement:

www.umlib.nl/taverne-license

Take down policy

If you believe that this document breaches copyright please contact us at:

repository@maastrichtuniversity.nl

providing details and we will investigate your claim.
}

Copyright and moral rights for the publications made accessible in the public portal are retained by the authors and/or other copyright owners and it is a condition of accessing publications that users recognise and abide by the legal requirements associated with these

- Users may download and print one copy of any publication from the public portal for the purpose of private study or research.

- You may not further distribute the material or use it for any profit-making activity or commercial gain

If the publication is distributed under the terms of Article $25 \mathrm{fa}$ of the Dutch Copyright Act, indicated by the "Taverne" license above, 
TECHNOLOGY INDICATORS: POPULATION, LABOUR AND SCHOOLING

- 1993 Report -

ROA-R-1994/2E

G.W.M. Ramaekers

J. Hoevenberg

RESEARCH CENTRE FOR EDUCATION AND THE LABOUR MARKET

Faculty of Economics and Business Administration

University of Limburg

Maastricht, April 1994 
CIP-GEGEVENS KONINKLIJKE BIBLIOTHEEK, DEN HAAG

Ramaekers, G.W.M.

Technology indicators: population, labour and schooling: 1993 report / G.W.M. Ramaekers, J. Hoevenberg. - Maastricht: Research Centre for Education and the Labour Market, Faculty of Economics and Business Administration, University of Limburg. - III., graf., tab. - ([Report] / Researchcentrum voor Onderwijs en Arbeidsmarkt, ISSN 0922-8098; ROA-R-1994/2E)

Met lit. opg.

ISBN 90-5321-130-6 geb.

Trefw.: onderwijs en arbeidsmarkt ; Nederland. 


\section{CONTENTS}

Page

LIST OF GRAPHS AND TABLES

1. INTRODUCTION

2. KEY INDICATORS

2.1. Introduction

2.2. Internationally comparable key indicators

2.2.1. Participation in dual education 2

2.2.2. Share of vocational education in total regular education 4

2.2.3. Age composition of the (active) population 6

$\begin{array}{ll}\text { 2.2.4. Participation in training } & 9\end{array}$

2.3. Key indicators available only for the Netherlands $\quad 12$

2.3.1. Share of technically trained persons in the total number of school-leavers and in the labour force 12

2.3.2. Proportion of apprenticeship labour in the labour volume of industrial sectors 13

$\begin{array}{ll}\text { 2.4. New key indicators } & 17\end{array}$

$\begin{array}{ll}\text { 2.4.1. Science and engineering degrees } & 17\end{array}$

2.4.2. Labour market position of technically trained school-leavers

2.4.3. R\&D personnel in the labour force 23

$\begin{array}{ll}\text { 2.4.4. Expenditure on education } & 24\end{array}$

2.4.5. Skill-level of the population 26

3. INCIDENTAL SURVEYS 27

3.1. Expenditure on education 27

3.1.1. Public expenditure on higher education in the EU 27

3.1.2. Public expenditure on labour market training 29

3.1.3. Expenditure on continuing vocational training 30

3.2. Participation in training by occupational sector 30

3.3. Social support for technological progress 32

4. INITIATIVES FOR GENERATING NEW INDICATORS 36

4.1. International Education Indicators 36

4.2. Synoptic tables on Continuing Vocational Training 38

5. CONCLUSIONS 39 
SOURCES

APPENDIXI : PREVIOUS STUDIES

APPENDIX II : CLASSIFICATION OF INDUSTRIAL SECTORS

APPENDIX III : INFORMATION RECEIVED FROM THE NETWORK

46

APPENDIX IV : ADDITIONAL TABLES

48 


\section{LIST OF GRAPHS AND TABLES}

International key indicators developed so far:

Graph 1 : Proportion of dual-system students in total population between the ages of 15 and $24 ; 1983-90$

Graph 2 : Indicator of the share of vocational education (second and third levels); 1975 , $1980,1985-90$

Graph 3a : Percentage shares of age groups in total population; $1980,1985-91$

Graph 3b : Percentage shares of age groups in active population; 1980, 1985-91

Graph 4a : Participation in training (in the wider sense) as a percentage of the potential labour force between the ages of 15 and 49; 1983-91

Graph 4b : Participation in training (in the narrow sense) as a percentage of the potential labour force between the ages of 15 and $49 ; 1983-91$

Dutch key indicators developed so far:

Graph 5a : Percentage share of the labour volume contributed by employees with primary level apprenticeship agreements, by industrial sectors; 1975, 1980, 1985-92

Graph 5b : Percentage share of the labour volume contributed by employees with secondary level apprenticeship agreements, by industrial sectors; 1975, 1980, 1985-92

\section{TABLES}

International key indicators developed so far:

Table 1 : Proportion of dual-system students in total population between the ages of 15 and 24; 1983-90

Table 2 : Indicator of the share of vocational education (second and third levels); 1975 , 1980, 1985-90

Table 3a : Percentage shares of age groups in total population; 1980, 1985-91

Table $3 b$ : Percentage shares of age groups in active population; 1980, 1985-91

Table 4a : Participation in training (in the wider sense) as a percentage of the potential labour force between the ages of 15 and $49 ; 1983-91$

Table 4b : Participation in training (in the narrow sense) as a percentage of the potential labour force between the ages of 15 and 49 ; 1983-91

Dutch key indicators developed so far:

Table 5 : Share of school-leavers and of the labour force who are technically trained, 1991/92-2000/01

Table 6a : Percentage share of the labour volume contributed by employees with primary 
level apprenticeship agreements, by industrial sectors; 1975, 1980, 1985-92

Table 6b : Percentage share of the labour volume contributed by employees with secondary level apprenticeship agreements, by industrial sectors; 1975, 1980, 1985-92

New key indicators:

Table 7 : Degrees awarded in natural science, mathematics and computer science and in engineering as a percentage of total degrees awarded, 1988

Table 8a : Unemployment rates among Dutch school-leavers about one year after leaving school, cohort 1989/90-1990/91

Table 8b : Under-utilization among Dutch school-leavers about one year after leaving school, cohort 1989/90-1990/91

Table 8c : Incorrect utilization among Dutch school-leavers about one year after leaving school, cohort 1989/90-1990/91

Incidental indicators:

Table 9 : Supply shortage of beta-researchers, in absolute numbers and as a percentage of the expected employment, 2006-2010

Table 10 : Availability of R\&D personnel in 1991

Table 11 : Public expenditure on education as a percentage of GDP in 1991

Table 12 : Public expenditure per capita on education in 1991

Table 13 : Percentage of the population aged 25 to 64 years that have completed higher education

Table 14a : Level of public expenditure on higher education, 1987

Table 14b: Changes in public expenditure on higher education, 1980-87 (in percentages)

Table 15 : Training for unemployed adults and those threatened by redundancy as a percentage of GDP

Table 16 : Percentage of the wage bill spend on continuing vocational training in 1990

Table 17a : Participation in training by occupational sector in 1991 for some member states of the European Union

Table 17b: Percentage-points change in participation in training by occupational sector for some member states of the European Union for the period 1987-1991

Table 18a : Social interest in discoveries, in selected EU member states (1989)

Table 18b : Social attitude towards science and technology, in selected EU member states (1989) 
-iii-

\section{ACKNOWLEDGEMENT}

The Directorate for General Technology Policy of the Dutch Ministry of Economic Affairs has developed a databank of indicators on the international economic position of the Netherlands with regard to the implementation of technology, called 'STEMMING'. One category of indicators of the STEMMING databank refers to the technological potential of the labour force as an indication of the societal breeding ground for technological development.

In 1989 the Directorate for General Technology Policy commissioned the Research Centre for Education and the Labour Market (ROA) to develop and yearly update the indicators referring to the technological potential of the labour force. This year's study has been carried out by Drs G.W.M. Ramaekers (project leader), assisted by M. Reiners. It is the fifth study carried out by the ROA in the framework of the STEMMING databank. Appendix I gives an overview of the previous studies.

From 1992 on, the Maastricht Economic Research institute on Innovation and Technology (MERIT) has been responsible for maintaining and further expanding the STEMMING databank. This means that ROA's contribution to STEMMING is channelled through MERIT. ROA's task is to update the present key indicators and if possible to broaden and improve the existing indicators on the basis of a periodic review of relevant initiatives from international organizations. The aim is to establish internationally comparable indicators on education and employment. 


\section{INTRODUCTION}

The relation between technological development on the one hand and education and labour on the other is one of mutual influence. For one thing, the training of the labour force is an important determinant of a country's Research \& Development capacity. The degree of skill of the labour force thus influences the innovative capacity of the society. On the other hand, technological progress has a tremendous impact not only on the growth of the national economy and the shifts in the economic structure, but also on the volume and composition of employment, the contents of jobs, the demand for certain skills, and hence the nature and level of the training required. In this respect, the degree of skill the labour force possesses is an important determinant of the diffusion potential of technological progress.

The Directorate for General Technology Policy of the Dutch Ministry of Economic Affairs has developed a databank of indicators on the international economic position of the Netherlands with regard to the implementation of technology, called 'STEMMING' (approximately translatable as 'tuning'). The organisation and objectives of the STEMMING databank are outlined in the report 'METING 2, Indicatoren voor de technologische positiebepaling van Nederland' (Ministry of Economic Affairs, 1990). One category of indicators of the STEMMING databank refers to the technological potential of the labour force as an indication of the breeding ground for technological development. In 1990 it was decided that ROA should focus on internationally comparable 'key indicators' of labour and training, developed in 1989 (see Van Dam and De Grip, 1990).

This year's study, like previous studies, is in two parts. The first part concerns the updating of the key indicators of the societal breeding ground for technological innovations, mostly on the basis of international statistical data sources of ILO, UNESCO, Eurostat, and OECD. In the second part of the study the network of statistical offices, research institutes and/or researchers was approached with a request for new figures to complete the existing key indicators and to explore the possibility of developing new indicators of population, labour and training. This network consists of some 60 statistical offices, research institutes and/or researchers in the Netherlands, Germany, France, the United Kingdom, Sweden and the United States. In this report, figures with respect to Germany before 1991 refer to the former West Germany. Figures with respect to Germany after the reunification in 1990 cover both East and West Germany. The second part of the study also includes the annual search for incidental surveys.

Chapter 2 of the report contains the updated key indicators developed so far, as well as some possible new indicators. Chapter 3 presents the main results of incidental surveys in the field of population, labour and training, which might be relevant to technology policy. In chapter 4 the main initiatives for generating internationally comparable figures on population, labour and training are presented. The report is rounded off by a summary of this year's findings and some evaluating remarks in chapter 5. A table of abbreviations and acronyms follows the summary. 


\section{KEY INDICATORS}

\subsection{Introduction}

This year, attention is in the first place focused on updating the 'key indicators' of the societal breeding ground for technological progress which have been developed so far:

1. relative participation in dual education;

2. the share of vocational education in total regular education;

3. the age composition of the (economically active) population;

4. the proportion of the labour force enroled in training courses;

5. the share of technically skilled people in the total number of school-leavers and in the labour force;

6. the labour-market situation for the technically skilled;

7. the proportion of apprenticeship labour in the labour volume of industrial sectors.

As in 1992, the labour-market situation for the technically skilled could not be updated this year. The calculation of this indicator relies on unemployment figures from the District Labour Exchange Bureaus. Due to a change in the regional organisation of the labour exchange system, introduced in 1992, reliable figures on the education of the unemployed are, even in 1993, not yet available. Hence, the latest updated version of this indicator was presented in the 1991 report. ${ }^{1}$ In presenting the updated key indicators, broadly the same classification is used as last year.

\subsection{Internationally comparable key indicators}

This section contains four of the updated key indicators which are internationally comparable:

1. the relative participation in dual education (section 2.2.1);

2. the share of vocational education in total regular education (section 2.2.2);

3. the age composition of the (economically active) population (section 2.2.3);

4. the proportion of the labour force enroled in training courses (section 2.2.4).

The first two indicators measure the contribution of initial education to the future breeding ground for technological advance. The third indicator measures the need for training to overcome present or possible future impediments to the further diffusion of technological progress. The fourth indicator represents the training efforts being made in response to such obstacles.

2.2.1. Participation in dual education

Dual education is the collective name for types of initial education that combine learning and

1. Van Dam, Lodder, Ramaekers (1991), pp. 5-6. 
$-3-$

working, thus providing the students with basic skills for their future careers. In the Netherlands, most dual education takes the form of apprenticeships. The participation of young people in dual education, as already pointed out in De Grip and Nusselder (1989), can be considered indicative of the scientific and technological breeding ground for, in particular, the diffusion of technological progress.

The number of students in dual education can be calculated from the results of the annual 'Labour Force Survey', carried out by Eurostat. In that survey, persons between the ages of 15 and 50 were asked to state the type and purpose of any training course ${ }^{2}$ they had been engaged in during four weeks preceding the survey. As in the previous year's report, we related the number of persons participating in dual education to ILO figures from the 'Yearbook of Labour Statistics' on the total number of persons in the 15-24 age bracket. This makes a comparison among countries possible.

Graph 1a. Proportion of dual-system students in total population between the ages 15 and $24 ; 1983$ 1990

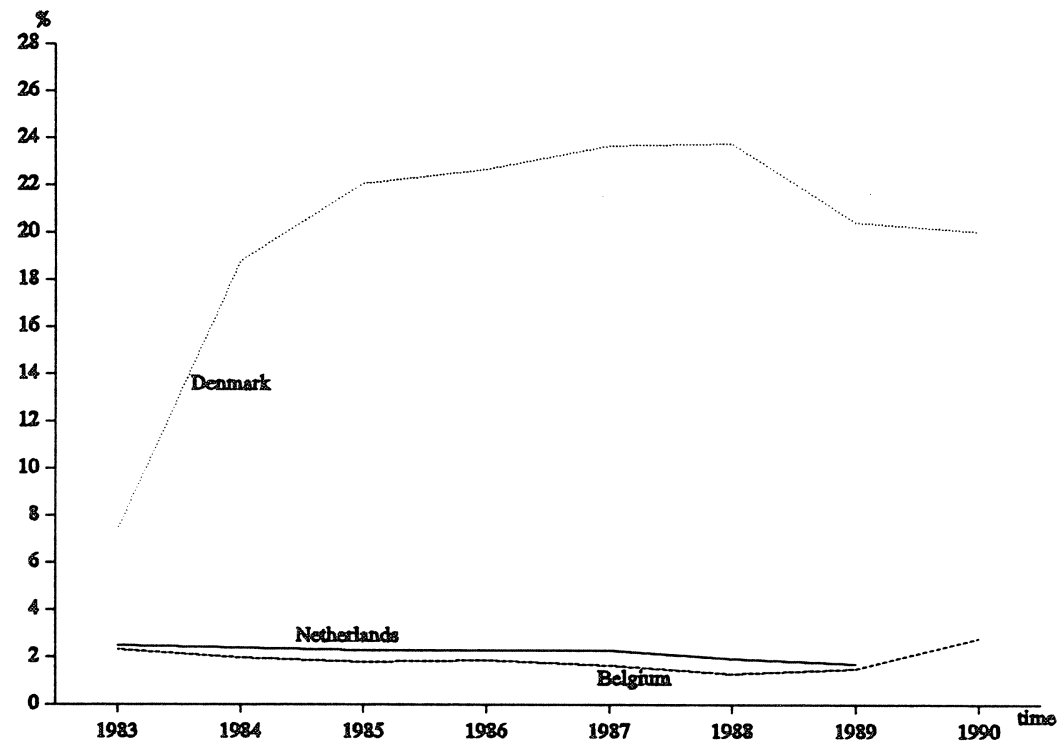

2. This survey makes a distinction between "apprenticeship" (learning contract) and other types of dual education. 
Graph 1a. Proportion of dual-system students in total population between the ages 15 and $24 ; 1983$ 1990 (continued)

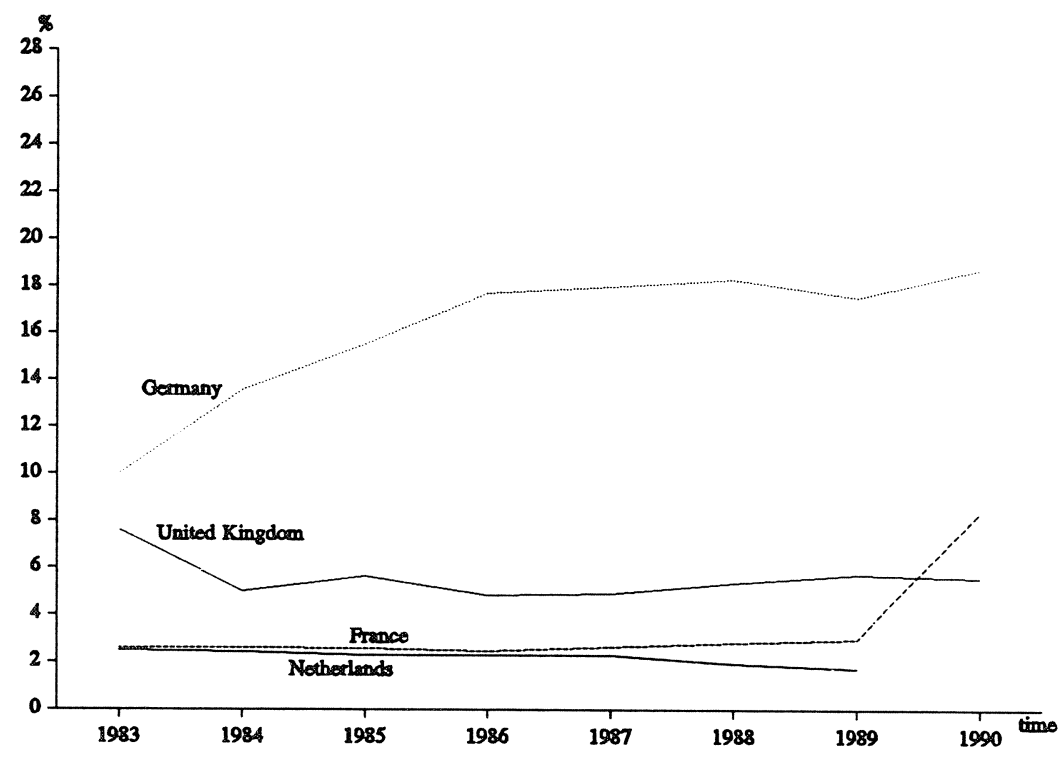

The data of graph 1 (and table 1 in appendix IV) may be slightly distorted by shifts in the nonresponse to the survey, and should therefore be interpreted with some caution. Nevertheless it is clear that dual education is much more important in Denmark (despite the decrease after 1988) and Germany than in the other countries investigated. The Netherlands are clearly at the lower end of the scale. The decrease in the percentage for the Netherlands which started in 1988 continued in 1989. Unfortunately the Labour Force Surveys for both 1990 and 1991 did not contain figures on the participation in dual education for the Netherlands. The increase in Belgium, starting in 1989 and continuing strongly in 1990, is related to a strong decrease in the 15-24 year age bracket and a substantial increase in the participation in apprenticeship education. The slight recovery which started in the second half of the eighties in France continues. The strong French increase in 1990 is related not only to a strong increase in the participation in apprenticeship education, but also to the fact that the 'dual system' is no longer categorised under the heading 'other' and so is included in the calculation of the indicator for the first time. The recovery in the United Kingdom seems to have stagnated. By contrast, in Luxembourg the declining tendency noticeable after 1985 continued in 1990. Ireland, Italy and Greece show a stable low picture (table 1 in appendix IV). For the time being this indicator is only available for the EU countries.

\subsubsection{Share of vocational education in total regular education}

This sub-section's indicator represents the share of vocational students (second and third levels) 
$-5-$

in the total number of second and third-level students. ${ }^{3}$ On the basis of the 'Statistical Yearbook' of UNESCO a division into vocational and general education is possible. To compose the indicator we have counted all third-level education (Higher Education) as vocational education.

This ratio indicates in particular the degree to which people in their later careers are open to technological progress. The underlying assumption is that workers with a broad initial vocational education tend to be more responsive to innovations than workers who have gained their skills in practice; the latter tend in particular to fall short on theoretical knowledge. Therefore, this indicator can be considered representative of the state of the scientific and technological breeding ground for the diffusion of technological change. A higher share of vocational education could also be considered to add to the society's innovative potential.

Graph 2. Indicator of the share of vocational education (second and third levels), 1975, 1980, 198590

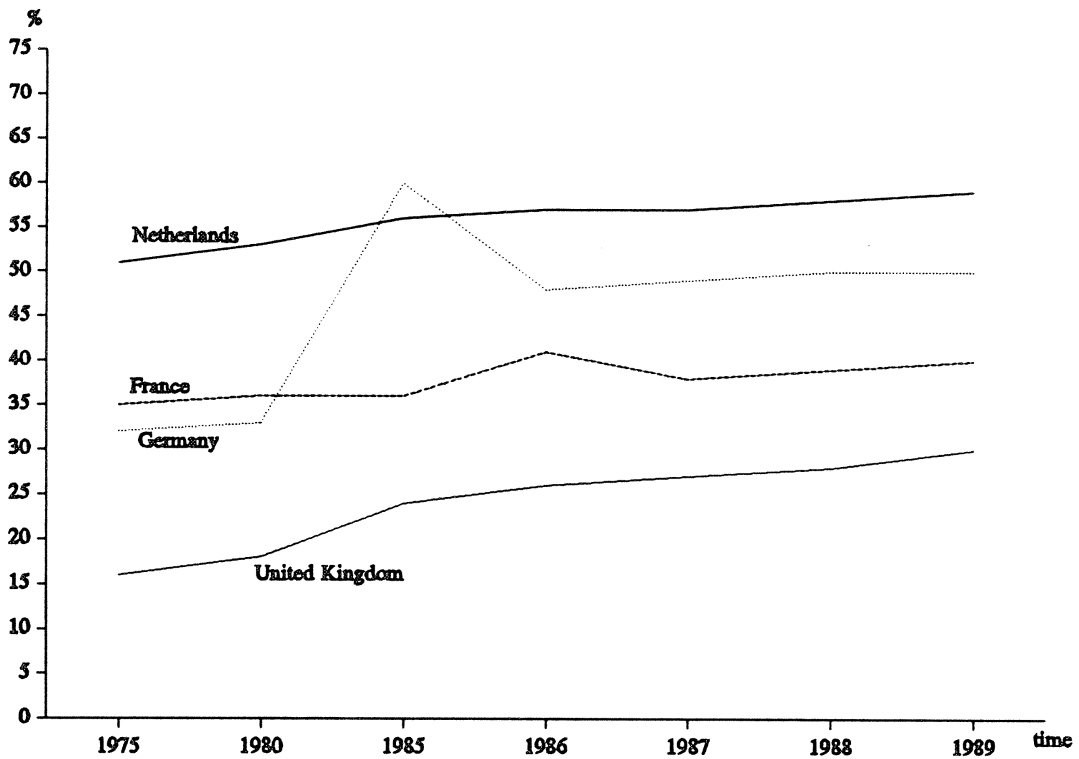

Table 2 in appendix IV shows that the Netherlands, Sweden and Germany have the highest proportion of students in vocational education, whereas in the United Kingdom and Japan it is much lower. Austria and France have an intermediate position. In the eighties the share of vocational education has shown a rising tendency in most countries, except in Sweden and in Japan. In Sweden the indicator remains stable at a high level. In Japan the rising tendency has only recently started, after a steadily declining tendency which lasted until 1985. As already pointed out in the previous report, the sharp increase in Germany in 1986, as compared with

3. The second and third levels comprise all education beyond the elementary stage. 
$-6-$

1985 , is due to a change in the definition of 'vocational training'.

In the Netherlands the share of vocational education is expected to increase further during the nineties, due to greater participation in higher education. The share of technical education is however expected to decrease, as can be seen in table 5 .

\subsubsection{Age composition of the (active) population}

Two indicators represent the age composition of the total population and the economically active population (labour force), respectively. These indicators measure the declining share of the young and the increasing share of the aged in the total and the economically active populations. To comply with the wishes of the Ministry of Economic Affairs, we will give an overall picture of the age composition of the (active) population rather than specific indicators of either share. The two indicators representing the age composition of the (active) populations are calculated on the basis of figures from the OECD's 'Labour Force Statistics' and the ILO's 'Yearbook of Labour Statistics'. The ILO defines the economically active population as all persons providing the supply of labour for the production of goods and services, including both employed and unemployed persons.

The share of older age groups in the active population can be considered a measure of the need for training, on the assumption that, as technological progress renders the labour force's initial training obsolete, retraining becomes necessary for the productive re-employment of the workers involved. In other words: the indicator measures the 'vulnerability' of the labour force to technological progress. It is also a measure of the 'intra-generational mobility' (De Grip, 1987) required to overcome any shifts which technological advance may cause in the occupational structure. The proportion of young people (15-24) in the active and overall population indicates the society's ability to respond to changed educational requirements due to technological progress by adjusting initial education to practical demands. However the adjustment of initial education to the developments on the labour market will have less effect as the proportion of young people in the labour force is lower.

Table 3a shows the size of the three age groups as proportions of the total population. It can be seen that in the Netherlands, France, Germany, the United Kingdom and Austria the 15-24 year age bracket has, over recent years, been declining as a proportion of the population, while Japan is experiencing a growing proportion of young people. In the United States the trend for the proportion of young people to decline came to an end at the beginning of the nineties. The proportionately smallest 15-24 age group is to be found in Sweden.

Among the European countries, the population of Germany has the largest group of over-50s. Japan is the only country that is experiencing increasing proportions in both the youngest and the older age groups. 
$-7-$

Table 3a. Percentage shares of age groups in total population; $1980,1985-91$

\begin{tabular}{|c|c|c|c|c|c|c|c|c|c|}
\hline & & $\begin{array}{r}1980 \\
\%\end{array}$ & $\begin{array}{r}1985 \\
\%\end{array}$ & $\begin{array}{r}1986 \\
\%\end{array}$ & $\begin{array}{r}1987 \\
\%\end{array}$ & $\begin{array}{r}1988 \\
\%\end{array}$ & $\begin{array}{r}1989 \\
\%\end{array}$ & $\begin{array}{r}1990 \\
\%\end{array}$ & $\begin{array}{r}1991 \\
\%\end{array}$ \\
\hline Netherlands & $\begin{array}{l}15-24 \\
25-49 \\
50-65\end{array}$ & $\begin{array}{l}17.3 \\
34.2 \\
14.4\end{array}$ & $\begin{array}{l}17.3 \\
36.5 \\
14.8\end{array}$ & $\begin{array}{l}17.2 \\
36.5 \\
14.7\end{array}$ & $\begin{array}{l}16.9 \\
37.4 \\
14.8\end{array}$ & $\begin{array}{l}16.6 \\
37.9 \\
14.7\end{array}$ & $\begin{array}{l}16.2 \\
38.4 \\
14.6\end{array}$ & $\begin{array}{l}15.7 \\
38.7 \\
14.7\end{array}$ & $\begin{array}{l}15.2 \\
39.3 \\
14.6\end{array}$ \\
\hline France & $\begin{array}{l}15-24 \\
25-49 \\
50-65\end{array}$ & $\begin{array}{l}15.9 \\
33.3 \\
15.3\end{array}$ & $\begin{array}{l}15.6 \\
34.1 \\
16.5\end{array}$ & $\begin{array}{l}15.5 \\
34.4 \\
16.4\end{array}$ & $\begin{array}{l}15.1 \\
35.0 \\
16.4\end{array}$ & $\begin{array}{l}15.9 \\
35.9 \\
15.8\end{array}$ & $\begin{array}{l}15.2 \\
35.3 \\
16.0\end{array}$ & $\begin{array}{l}15.0 \\
35.7 \\
15.6\end{array}$ & $\begin{array}{l}14.7 \\
36.1 \\
15.3\end{array}$ \\
\hline Germany & $\begin{array}{l}15-24 \\
25-49 \\
50-65\end{array}$ & $\begin{array}{l}15.6 \\
34.1 \\
16.2\end{array}$ & $\begin{array}{l}16.5 \\
35.2 \\
18.4\end{array}$ & $\begin{array}{l}16.3 \\
35.4 \\
18.4\end{array}$ & $\begin{array}{l}15.7 \\
35.6 \\
18.6\end{array}$ & $\begin{array}{l}15.0 \\
35.6 \\
18.9\end{array}$ & $\begin{array}{l}14.3 \\
36.0 \\
19.1\end{array}$ & $\begin{array}{l}13.8 \\
36.2 \\
19.5\end{array}$ & $\begin{array}{l}-- \\
--- \\
--\end{array}$ \\
\hline United Kingdom & $\begin{array}{l}15-24 \\
25-49 \\
50-65\end{array}$ & -- & -- & $\begin{array}{l}16.3 \\
33.2 \\
16.2\end{array}$ & -- & $\begin{array}{l}15.7 \\
33.9 \\
15.9\end{array}$ & -- & $\begin{array}{r}14.8 \\
40.4^{*} \\
10.2\end{array}$ & -- \\
\hline Sweden & $\begin{array}{l}15-24 \\
25-49 \\
50-65\end{array}$ & $\begin{array}{l}12.0 \\
33.4 \\
17.3\end{array}$ & $\begin{array}{l}12.6 \\
34.4 \\
16.3\end{array}$ & $\begin{array}{l}12.6 \\
34.3 \\
16.2\end{array}$ & $\begin{array}{l}12.7 \\
34.8 \\
15.7\end{array}$ & -- & $\begin{array}{l}12.5 \\
35.0 \\
15.3\end{array}$ & $\begin{array}{l}12.4 \\
35.2 \\
15.2\end{array}$ & -- \\
\hline Austria & $\begin{array}{l}15-24 \\
25-49 \\
50-65\end{array}$ & $\begin{array}{l}14.4 \\
34.0 \\
15.6\end{array}$ & $\begin{array}{l}16.9 \\
34.0 \\
16.6\end{array}$ & $\begin{array}{l}16.7 \\
34.6 \\
16.3\end{array}$ & $\begin{array}{l}16.3 \\
35.3 \\
16.0\end{array}$ & $\begin{array}{l}15.9 \\
35.9 \\
15.8\end{array}$ & $\begin{array}{l}15.4 \\
36.2 \\
15.8\end{array}$ & $\begin{array}{l}15.1 \\
36.3 \\
16.1\end{array}$ & -- \\
\hline United States & $\begin{array}{l}15-24 \\
25-49 \\
50-65\end{array}$ & $\begin{array}{l}16.9 \\
32.4 \\
14.7\end{array}$ & $\begin{array}{l}16.6 \\
35.8 \\
13.9\end{array}$ & $\begin{array}{l}16.2 \\
36.4 \\
13.7\end{array}$ & $\begin{array}{l}15.7 \\
37.0 \\
13.5\end{array}$ & $\begin{array}{l}15.2 \\
37.4 \\
13.4\end{array}$ & $\begin{array}{l}13.5 \\
38.1 \\
13.4\end{array}$ & $\begin{array}{l}14.7 \\
37.8 \\
13.3\end{array}$ & $\begin{array}{l}14.4 \\
35.8 \\
12.9\end{array}$ \\
\hline Japan & $\begin{array}{l}15-24 \\
25-49 \\
50-65\end{array}$ & $\begin{array}{l}13.8 \\
38.9 \\
14.7\end{array}$ & $\begin{array}{l}14.2 \\
37.2 \\
16.8\end{array}$ & $\begin{array}{l}14.4 \\
36.9 \\
17.2\end{array}$ & $\begin{array}{l}14.7 \\
36.5 \\
17.5\end{array}$ & $\begin{array}{l}15.0 \\
36.3 \\
17.8\end{array}$ & $\begin{array}{l}15.2 \\
36.2 \\
18.0\end{array}$ & $\begin{array}{l}15.3 \\
36.2 \\
18.2\end{array}$ & $\begin{array}{l}15.5 \\
35.8 \\
18.5\end{array}$ \\
\hline
\end{tabular}

Source: ILO/OECD/ROA

Legend: $---=$ not available

* In 1990 the age groups 45-49 and 50-54 in the United Kingdom have been joined to one age group. This 45-54 age group is included under the heading 25-49.

Table $3 \mathrm{~b}$ shows the shares of the same three age groups in the economically active population. This table shows that the proportion of 15-24 year olds in the economically active population is highest in the Netherlands, the United Kingdom and Austria, whereas the share of the over-50s in the active population is highest in Germany, Sweden and Japan. That group's share has even increased in Japan and Germany over recent years. 
$-8-$

Table 3b. Percentage shares of age groups in active population; $1980,1985-91$

\begin{tabular}{|c|c|c|c|c|c|c|c|c|c|}
\hline & & $\begin{array}{r}1980 \\
\%\end{array}$ & $\begin{array}{r}1985 \\
\%\end{array}$ & $\begin{array}{r}1986 \\
\%\end{array}$ & $\begin{array}{r}1987 \\
\%\end{array}$ & $\begin{array}{r}1988 \\
\%\end{array}$ & $\begin{array}{r}1989 \\
\%\end{array}$ & $\begin{array}{r}1990 \\
\%\end{array}$ & $\begin{array}{r}1991 \\
\%\end{array}$ \\
\hline Netherlands & $\begin{array}{l}15-24 \\
25-49 \\
50-65\end{array}$ & $\begin{array}{l}21.6 \\
59.7 \\
17.2\end{array}$ & $\begin{array}{l}20.5 \\
63.9 \\
15.0\end{array}$ & $\begin{array}{l}20.2 \\
64.6 \\
14.7\end{array}$ & $\begin{array}{l}22.6 \\
63.7 \\
12.0\end{array}$ & $\begin{array}{l}22.0 \\
64.5 \\
13.5\end{array}$ & $\begin{array}{l}21.3 \\
65.3 \\
13.4\end{array}$ & $\begin{array}{l}20.9 \\
65.8 \\
13.3\end{array}$ & $\begin{array}{l}20.3 \\
66.8 \\
12.9\end{array}$ \\
\hline France & $\begin{array}{l}15-24 \\
25-49 \\
50-65\end{array}$ & $\begin{array}{l}17.2 \\
60.4 \\
21.0\end{array}$ & $\begin{array}{l}15.8 \\
64.1 \\
19.2\end{array}$ & $\begin{array}{l}15.3 \\
65.0 \\
18.9\end{array}$ & $\begin{array}{l}13.6 \\
66.6 \\
18.9\end{array}$ & $\begin{array}{l}-- \\
\cdots \\
--\end{array}$ & $\begin{array}{l}13.3 \\
67.3 \\
18.5\end{array}$ & $\begin{array}{l}12.4 \\
68.5 \\
18.3\end{array}$ & $\begin{array}{l}11.6 \\
69.9 \\
17.7\end{array}$ \\
\hline Germany & $\begin{array}{l}15-24 \\
25-49 \\
50-65\end{array}$ & $\begin{array}{l}20.6 \\
58.1 \\
19.6\end{array}$ & $\begin{array}{l}21.2 \\
58.2 \\
19.5\end{array}$ & $\begin{array}{l}20.9 \\
58.2 \\
19.9\end{array}$ & $\begin{array}{l}20.2 \\
58.4 \\
20.3\end{array}$ & $\begin{array}{l}19.5 \\
58.6 \\
21.0\end{array}$ & $\begin{array}{l}18.3 \\
59.6 \\
21.3\end{array}$ & $\begin{array}{l}17.3 \\
59.6 \\
22.1\end{array}$ & $\begin{array}{l}-- \\
--- \\
--\end{array}$ \\
\hline United Kingdom & $\begin{array}{l}15-24 \\
25-49 \\
50-65\end{array}$ & $\begin{array}{l}-- \\
-- \\
--\end{array}$ & $\begin{array}{l}-- \\
-- \\
--\end{array}$ & $\begin{array}{l}22.9 \\
55.3 \\
13.0\end{array}$ & $\begin{array}{l}-- \\
--\end{array}$ & $\begin{array}{l}22.3 \\
56.4 \\
19.8\end{array}$ & $\begin{array}{l}-- \\
--- \\
--\end{array}$ & $\begin{array}{r}20.9 \\
66.8^{\circ} \\
10.7\end{array}$ & $\begin{array}{l}--- \\
--- \\
---\end{array}$ \\
\hline Sweden & $\begin{array}{l}15-24 \\
25-49 \\
50-65\end{array}$ & $\begin{array}{l}14.5 \\
58.5 \\
25.3\end{array}$ & $\begin{array}{l}15.7 \\
60.1 \\
22.9\end{array}$ & $\begin{array}{l}16.2 \\
60.4 \\
23.4\end{array}$ & $\begin{array}{l}16.0 \\
61.3 \\
22.7\end{array}$ & $\begin{array}{l}-- \\
-- \\
--\end{array}$ & $\begin{array}{l}16.3 \\
61.5 \\
22.1\end{array}$ & $\begin{array}{l}15.8 \\
61.9 \\
22.3\end{array}$ & $\begin{array}{l}14.9 \\
62.5 \\
22.6\end{array}$ \\
\hline Austria & $\begin{array}{l}15-24 \\
25-49 \\
50-65\end{array}$ & $\begin{array}{l}19.7 \\
59.8 \\
19.8\end{array}$ & $\begin{array}{l}24.1 \\
59.8 \\
15.6\end{array}$ & $\begin{array}{l}23.9 \\
60.7 \\
14.9\end{array}$ & $\begin{array}{l}23.7 \\
61.4 \\
14.4\end{array}$ & $\begin{array}{l}22.7 \\
62.7 \\
14.2\end{array}$ & $\begin{array}{l}21.7 \\
63.5 \\
14.4\end{array}$ & $\begin{array}{l}20.8 \\
63.6 \\
15.1\end{array}$ & $\begin{array}{l}--- \\
--- \\
---\end{array}$ \\
\hline United States & $\begin{array}{l}15-24 \\
25-49 \\
50-65\end{array}$ & $\begin{array}{l}23.0 \\
54.6 \\
19.3\end{array}$ & $\begin{array}{l}20.2 \\
58.8 \\
17.1\end{array}$ & $\begin{array}{l}19.8 \\
60.6 \\
17.0\end{array}$ & $\begin{array}{l}19.2 \\
61.5 \\
16.8\end{array}$ & $\begin{array}{l}18.3 \\
61.3 \\
16.4\end{array}$ & $\begin{array}{l}17.6 \\
61.9 \\
16.4\end{array}$ & -- & $\begin{array}{l}16.3 \\
63.3 \\
16.5\end{array}$ \\
\hline Japan & $\begin{array}{l}15-24 \\
25-49 \\
50-65\end{array}$ & $\begin{array}{l}12.4 \\
61.6 \\
21.0\end{array}$ & $\begin{array}{l}12.3 \\
59.3 \\
23.4\end{array}$ & $\begin{array}{l}12.5 \\
58.6 \\
23.8\end{array}$ & $\begin{array}{l}12.6 \\
58.1 \\
24.2\end{array}$ & $\begin{array}{l}12.7 \\
57.5 \\
24.6\end{array}$ & $\begin{array}{l}12.9 \\
57.1 \\
24.6\end{array}$ & $\begin{array}{l}13.1 \\
56.5 \\
24.8\end{array}$ & $\begin{array}{l}13.4 \\
55.4 \\
25.2\end{array}$ \\
\hline
\end{tabular}

Source: ILO/OECD/ROA

Legend: $---=$ not available

* In 1990 the age groups 45-49 and 50-54 in the United Kingdom have been joined to one age group. This 45-54 age group is included under the heading 25-49.

The lowest proportion of people between the ages of 50 and 65 in the active population is to be found in the Netherlands, where it also declined considerably in the 1980s. The same pattern, though somewhat less marked, applies to most other countries.

The still relatively young active population in the Netherlands indicates a low vulnerability of the Dutch labour force to technological progress. Moreover, due to the high proportion of young people (15-24) in the Dutch active population, adjustment of initial education to labour market developments will have greater effect in the Netherlands. However, population forecasts show that the potential labour force $(15-65)$ in the Netherlands is aging. The proportion of young 
$-9-$

people (15-24) is expected to drop until 2005, after which it is expected to increase again slightly. By contrast, a clear increase in the share of the older age brackets (25-65) in the potential labour force is perceived. Presumably, the process of aging will continue to around 2030.

\subsubsection{Participation in training}

Training is an important means of responding to technological progress. Hence, participation in training is a good indication of the upgrading of employment by means of training policies. The 'Labour Force Survey', conducted yearly by Eurostat for the European Union, produces data on the respondents' participation in training during the four weeks preceding the survey. Persons between the ages of 15 and 50 are asked to state what training they were participating in and for what purpose. From this data we can derive the proportion of the potential labour force between the ages of 15 and 50 who participate in training. This indicator can be calculated in either a narrow or a wide sense. Participation in training in the wide sense refers to 'on-the-job' training, apprenticeships, dual system training, and all other types of training that can be combined with a job (see graph $4 a$ and table $4 a$ in appendix IV). The indicator in the narrow sense (see graph $4 \mathrm{~b}$ and table $4 \mathrm{~b}$ in appendix IV), on the contrary, is limited to 'on-the-job training', leaving out the more elementary vocational types of training (apprenticeship etc.). To calculate the indicators, the number of people who participated in training in the four weeks before the survey has been related to the total population aged between 15 and 49 . These indicators can be considered as measures of the scientific and technological breeding ground for the diffusion of technological progress. Unfortunately the 'Labour Force Surveys' of 1990 and 1991 did not contain figures for participation in on-the-job training, apprenticeships, dual system training, and other types of training that can be combined with a job for the Netherlands.

Rising skill requirements can be met by adjusting the initial education system or the population's participation in initial education (educational policy) and by having the current labour force participate in additional training (training policy). 
Graph 4a. Participation in training (in the wide sense) as a percentage of the potential labour force between the ages 15 and 49; 1983-1991
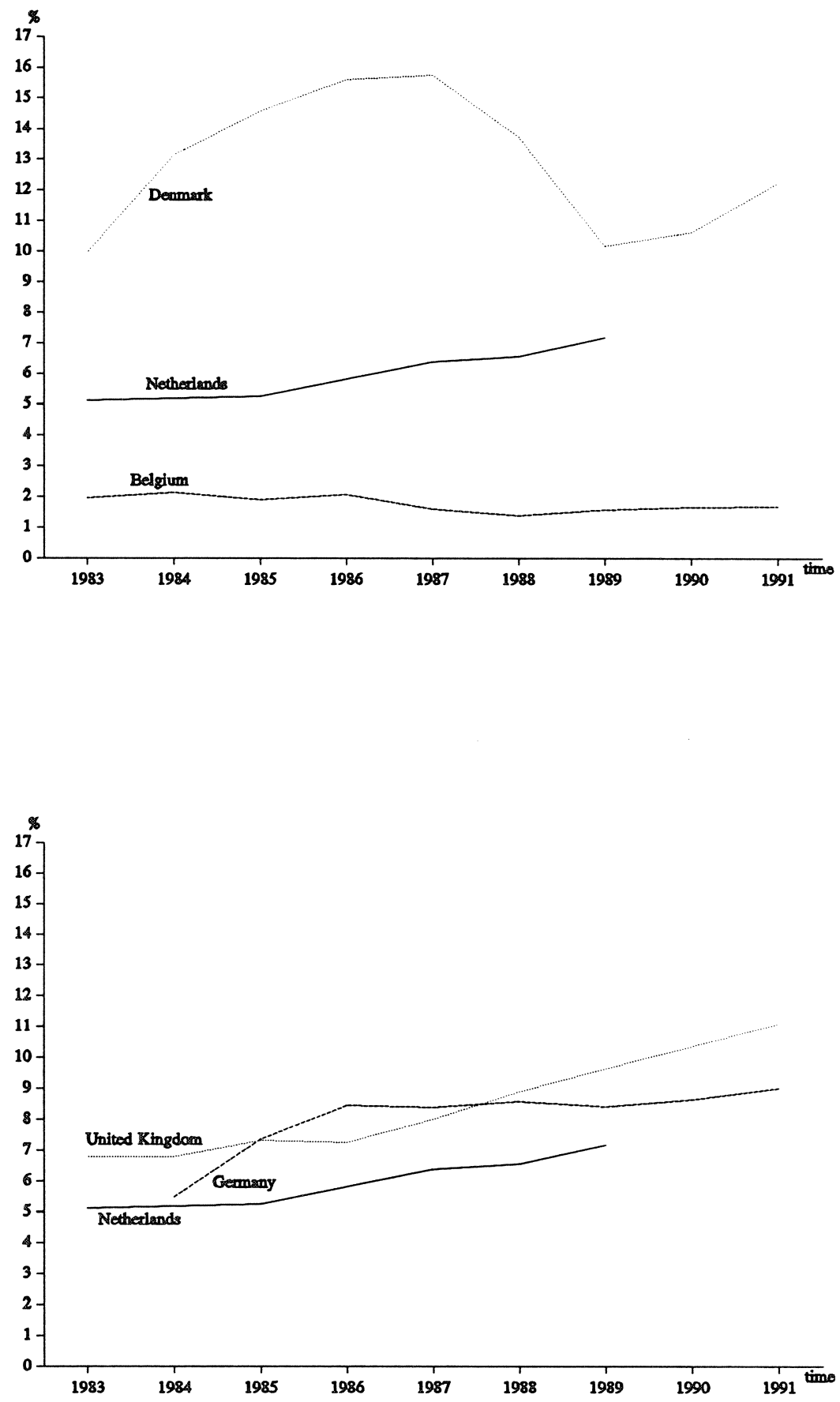

From graph $4 a$ it can be seen that in Denmark, the Netherlands, the United Kingdom and Germany, in particular, participation in training is of great importance. It can also be seen that during the second half of the eighties the participation in training increased in the Netherlands, the United Kingdom and Germany, while in Denmark it decreased. Since 1990, the already high 
training participation rates in Germany, the United Kingdom and Denmark have risen further.

Graph 4b. Participation in training (in the narrow sense) as a percentage of the potential labour force between the ages 15 and $49 ; 1983-1991$
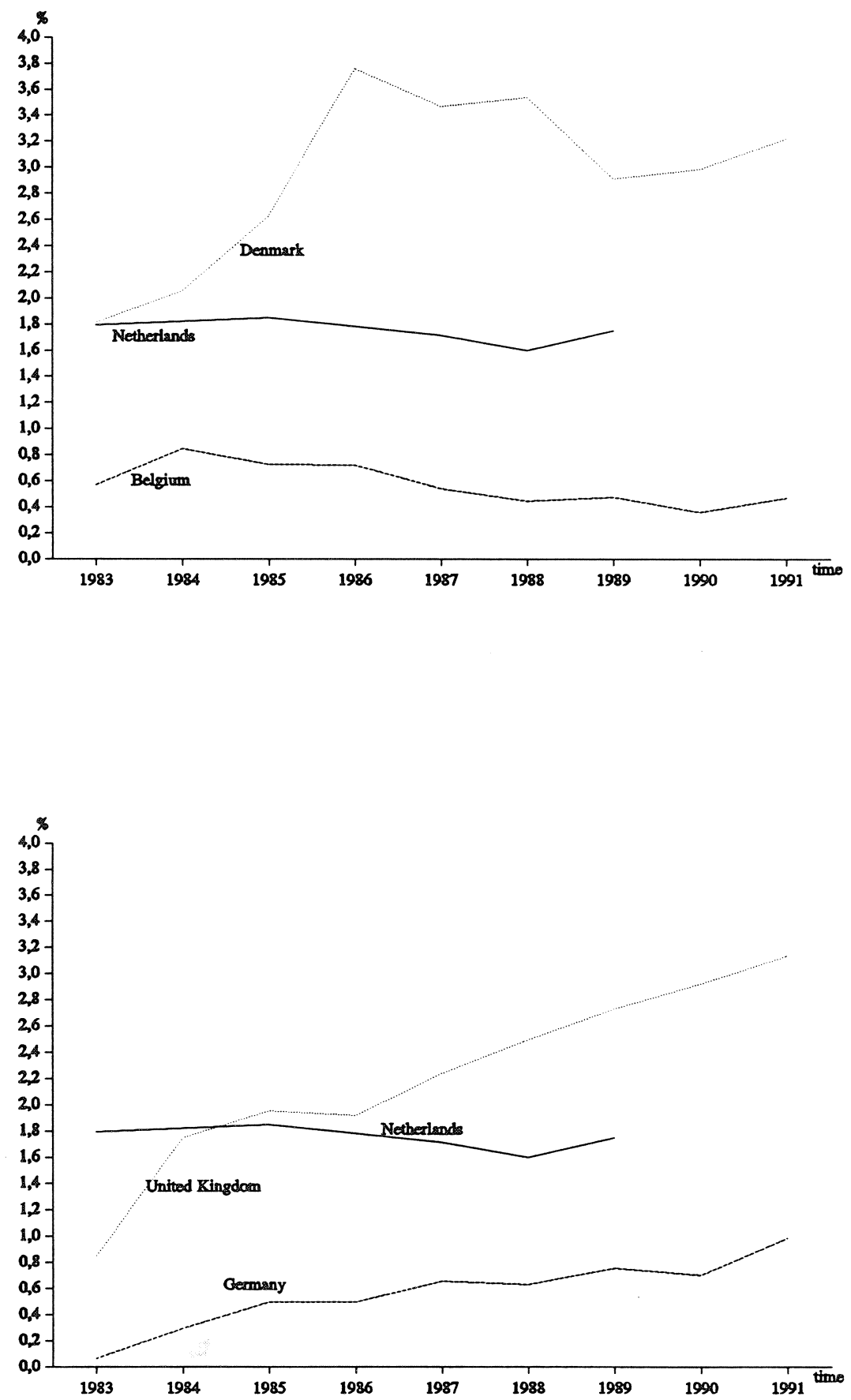

Graph $4 \mathrm{~b}$ represents participation in training in the narrow sense, only 'on-the-job training' being considered. The pattern of this indicator largely coincides with that of the indicator discussed 
above, although the participation in training in the narrow sense amounts to only 1 to 3 percent. With regard to this indicator, Denmark and the United Kingdom are the leading countries, followed by Ireland and the Netherlands. A striking feature is the relatively low participation in training in Germany (a country known for its well-developed initial dual education).

\subsection{Key indicators available only for the Netherlands}

This section contains two updated key indicators which are available only for the Netherlands:

1. the share of technically skilled people in the total number of school-leavers and in the labour force (section 2.3.1);

2. the number of apprenticeship agreements per industrial sector, expressed as a proportion of the labour volume of the sector (section 2.3.2).

The first indicator measures how far the contemporary (potential) labour force functions as a breeding ground for technological progress, and measures the dynamics of the breeding ground for technological progress. The second indicator represents the training efforts being made in response to obstacles to the further diffusion of technological progress.

2.3.1. Share of technically trained persons in the total number of school-leavers and in the labour force

This section presents two sub-indicators of the share of technically trained persons in the total number of school-leavers, and in the labour force. A similar indicator relates the proportion of technically trained school-leavers to that of the potential labour force. As indicated in the 1990 report (see Van Dam and De Grip, 1990), the share of technically trained persons in the labour force measures the health of the scientific and technological breeding ground of society in terms of innovation as well as diffusion. The sub-indicator referring to school-leavers and, especially, the indicator relating the number of technically trained school-leavers to the technically trained labour force (column 3 of table 5) are the more dynamic measures of the evolution of this breeding ground.

The share of technically trained workers in the labour force was last updated on the basis of 1990 figures, since the annual 'SKILL' forecasts of the Ministry of Education and Science (MOW) which were used for updating this indicator were replaced in 1991 by the 'Referentieraming' of the MOW, which do not contain data on the education of the labour force.

The updated sub-indicator of the first column in table 5 shows a declining trend in the share of technically trained persons in the classes of school-leavers in the 1990s, while the share of technically trained workers in the labour force will increase still further. As a result, the ratio of the proportion of each cohort of school-leavers who are technically educated to the proportion of the labour force having a technical education will further decrease. In absolute numbers this means that the annual outflow of technically educated school-leavers will decrease from 
54,000 in 1991 to 48,000 in 2000 , whereas the number of technically educated in the labour increases from 2.1 million in 1991 to 2.2 million in the year 2000 .

Table 5. Share of school-leavers and of the labour force who are technically trained, 1991/922000/01

\begin{tabular}{lccc}
\hline & $\begin{array}{c}\text { School-leavers } \\
\%^{1}\end{array}$ & $\begin{array}{c}\text { Labour force } \\
\%^{2}\end{array}$ & $\begin{array}{c}\text { Indicator } \\
\%^{3}\end{array}$ \\
\hline $1991 / 1992$ & 22.6 & 22.5 & 100 \\
$1992 / 1993$ & 22.4 & 22.6 & 99 \\
$1993 / 1994$ & 22.1 & 22.7 & 97 \\
$1994 / 1995$ & 22.1 & 22.8 & 97 \\
$1995 / 1996$ & 21.9 & 22.9 & 96 \\
$1996 / 1997$ & 21.7 & 22.9 & \\
$1997 / 1998$ & 21.3 & & 95 \\
$1998 / 1999$ & 20.9 & & 90 \\
$1999 / 2000$ & 20.8 & 23.0 & \\
$2000 / 2001$ & 20.7 & & \\
\hline
\end{tabular}

Source: MOW (1990,1993)/ROA

Legend:

$1=$ Share of technically trained in the cohort of school-leavers (based on 1993 forecasts).

$2=$ Share of technically trained workers in the labour force (based on 1990 forecasts). These 1990 forecasts are based on the former 'SKILL forecasts' of the MOW because it's successor, the 'Referentieraming', does not provide data on the education of the labour force.

$3=$ Ratio of the share of technically trained persons in the cohort of school-leavers to the proportion of the labour force having a technical education.

\subsubsection{Proportion of apprenticeship labour in the labour volume of industrial sectors}

This subsection presents an indicator which shows the percentage share of employees with either primary (graph $5 \mathrm{a}$, and table $6 \mathrm{a}$ in appendix IV) or secondary (graph $5 \mathrm{~b}$, and table $6 \mathrm{~b}$ in appendix IV) level apprenticeship agreements in the labour volume of industrial sectors in the Netherlands. In primary level apprenticeships people are trained till they reach the level of being able to begin work in a trade or profession. Secondary level apprenticeships enlarge the professional skills until the person can execute his professional tasks on his own. The formal duration of the education in primary level apprenticeships is two or three years. In secondary level apprenticeships it is one or two years.

This indicator is calculated on the basis of:

1. the number of primary and secondary level apprentices participating in the apprenticeship system (supplied annually by the training institutions and collected by the CBS);

2. data on the labour volume of industrial sectors (supplied annually by the CPB).

The indicator has been calculated for seven industrial sectors, defined by the CORO. Appendix 1 shows which of the industrial sectors defined by the CPB and which training institutions from 
the CBS data are linked to the sectors defined by the CORO. ${ }^{4}$

The labour volume for each sector is determined by adding the labour volumes of a number of corresponding CPB industrial sectors. The number of primary and secondary level apprenticeships for each sector is determined by aggregating the primary and secondary apprenticeships of various training institutions. In calculating the apprentices' share in the labour volume, an apprenticeship is considered as a job in which one works for $80 \%$ of a fiveday labour week (since apprentices in general spend one day per week in school). Therefore the number of apprenticeships has been multiplied by the labour hour factor of 0.8 . The graphs represent the percentage shares of primary apprentices' labour (graph $5 a$, and table $6 a$ in appendix IV) and secondary apprentices' labour (graph 5b, and table $6 \mathrm{~b}$ in appendix IV) in the labour volume of industrial sectors.

Graph 5a. Percentage share of the labour volume contributed by employees with primary level apprenticeship agreements, by industrial sectors; 1975, 1980, 1985-1992

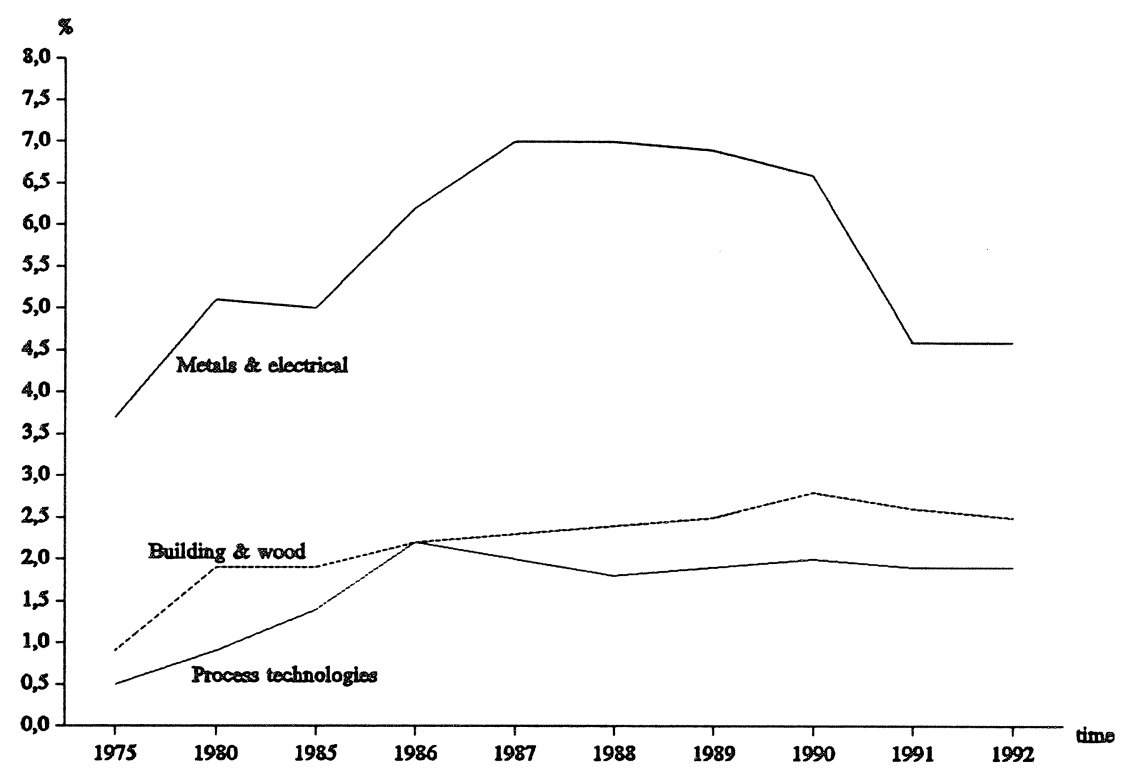

4. See the table of abbreviations after chapter 5 for an explanation of the abbreviations and acronyms in this report. 
Graph 5a. Percentage share of the labour volume contributed by employees with primary level apprenticeship agreements, by industrial sectors; 1975, 1980, 1985-1992 (continued)

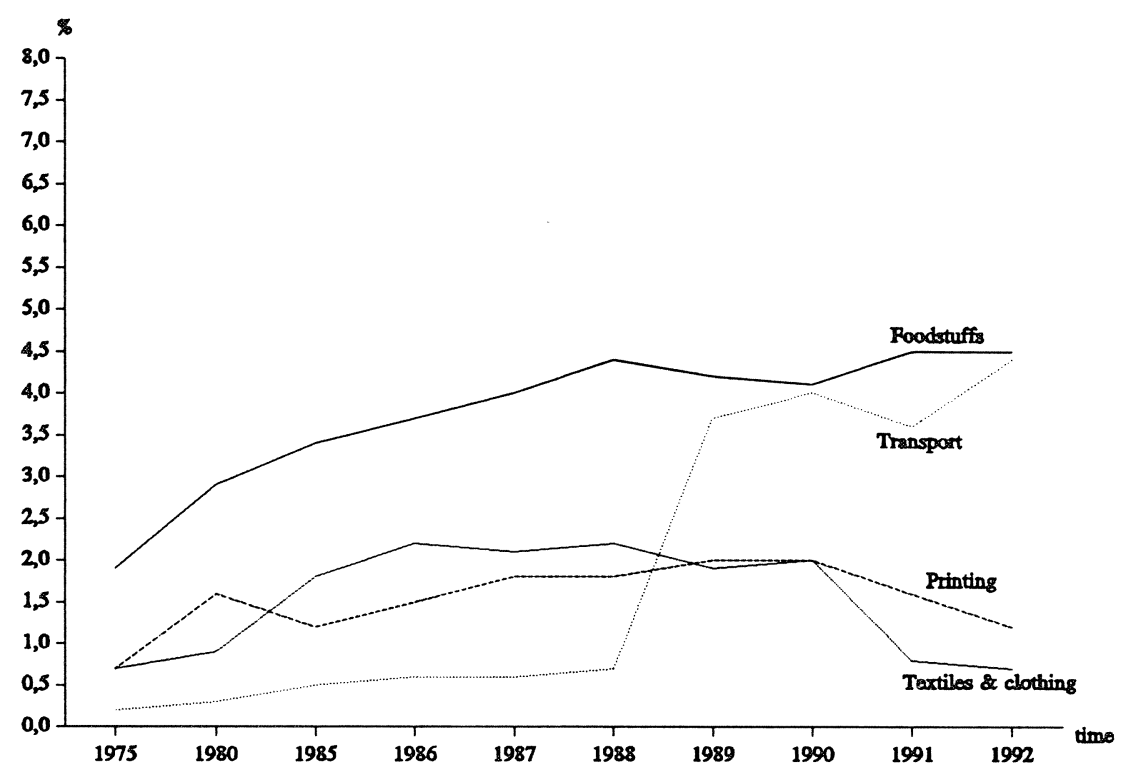

Graph $5 \mathrm{a}$ shows that the number of primary level apprenticeships increased until the second half of the eighties, after which it began to decline. This general picture applies to all sectors, except the foodstuffs and transport sectors where the share of primary level apprenticeships continues to increase. The share of primary level apprenticeships is at the moment highest in the metals and electrical sector, the foodstuffs sector, and the transport sector. The declining share of primary level apprenticeships at the end of the eighties is primarily related to a decrease in the supply of new apprentices due to the declining flows of students coming from lower vocational education and intermediate general education, which form the traditional preparatory education for primary level apprenticeship education. The low outflow from this traditional preparatory education is caused by:

- demographic developments;

- the increasing flow into further education within full time education;

- the negative image of lower vocational education.

An additional problem is the high percentage of apprentices who don't finish their education (De Grip, et al., 1993, p. 2).

For paid working school-leavers from Lower Vocational Education and Lower General Secondary Education, the apprenticeship system is the most important form of vocational education. Of the 40,000 paid working school-leavers from 1991, 53\% entered the apprenticeship system in 1992. Only $9 \%$ entered other forms of vocational training offered by private organizations, business organizations or adult education (Adviescentrum Opleidingsvraagstukken).

A study by ROA showed that the inflow to primary level apprenticeships is expected to 
decrease from over 45,000 in 1991 to somewhat less than 37,000 in 1997 (a decrease by $18 \%$ ) and further to some 33,500 in 2001 (a further decrease by almost 10\%). These expected developments in the inflow of new apprentices, when confronted with the expected demand for new students, would indicate a supply shortage of 12,000 new apprentices in 1997 . This amounts to $25 \%$ of the inflow planned by the apprenticeship supervisory boards. In the long term the supply shortage is expected to increase even further, to 16,000 students in the year 2001 , or almost one third $(32 \%)$ of the planned inflow of new students. The number of apprentices who finish their primary level training is expected to decrease from over 22,000 in 1991 to 16,000 in 1997 ( $28 \%$ below the 1991 level), and subsequently to 19,600 in 2001 which is $12 \%$ below the 1991 level. (De Grip, et al., 1993, pp. 66-67).

Graph $5 b$ (table $6 b$ in appendix IV) gives the share of secondary level apprenticeships in each industrial sector. As can be seen, the shares of secondary level apprenticeships in the labour volume of industrial sectors are lower than the shares for primary level apprenticeships. This indicates that only some of the primary level apprentices go on to secondary level apprenticeships, with the flow-through rate being highest in the process technologies sector. Participation in secondary level apprenticeships, as for primary level apprenticeships, increased during the eighties. This participation is now highest in the metals and electrical sector, the foodstuffs sector and the process technologies sector. Since 1990, participation in secondary level apprenticeships appears to have stabilized in most sectors.

Graph 5b. Percentage share of the labour volume contributed by employees with secondary level apprenticeship agreements, by industrial sectors; 1975, 1980, 1985-1992

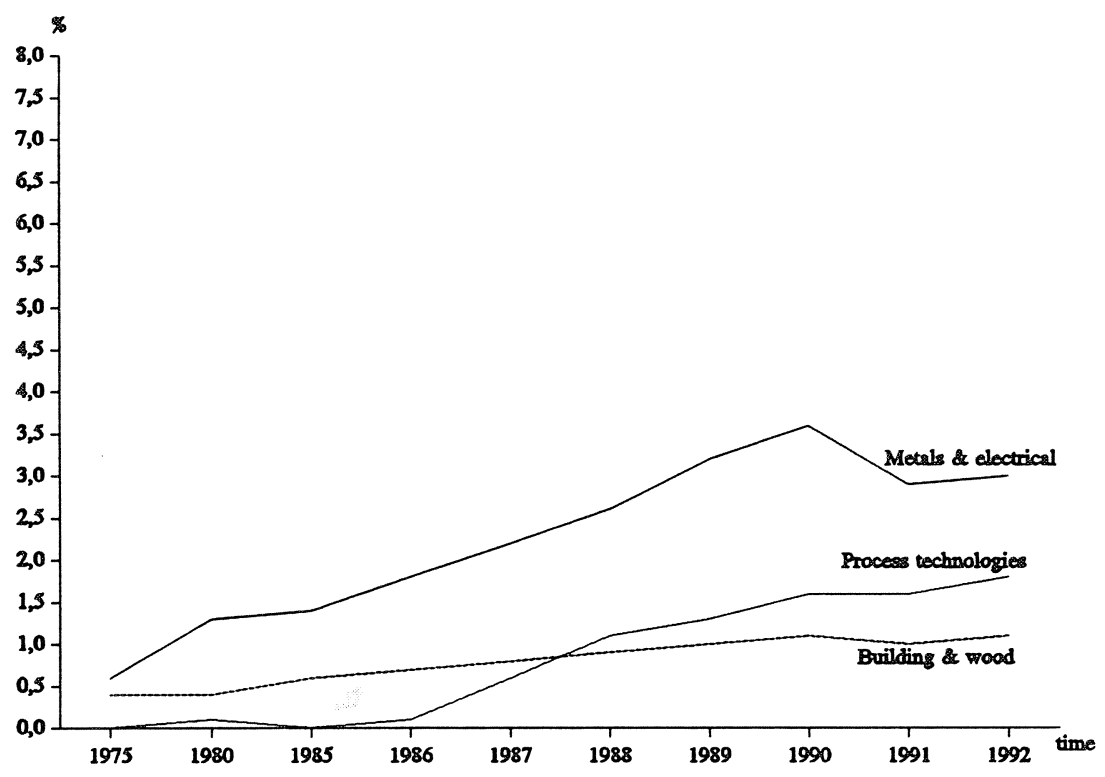


Graph 5b. Percentage share of the labour volume contributed by employees with secondary level apprenticeship agreements, by industrial sectors; 1975, 1980, 1985-1992 (continued)

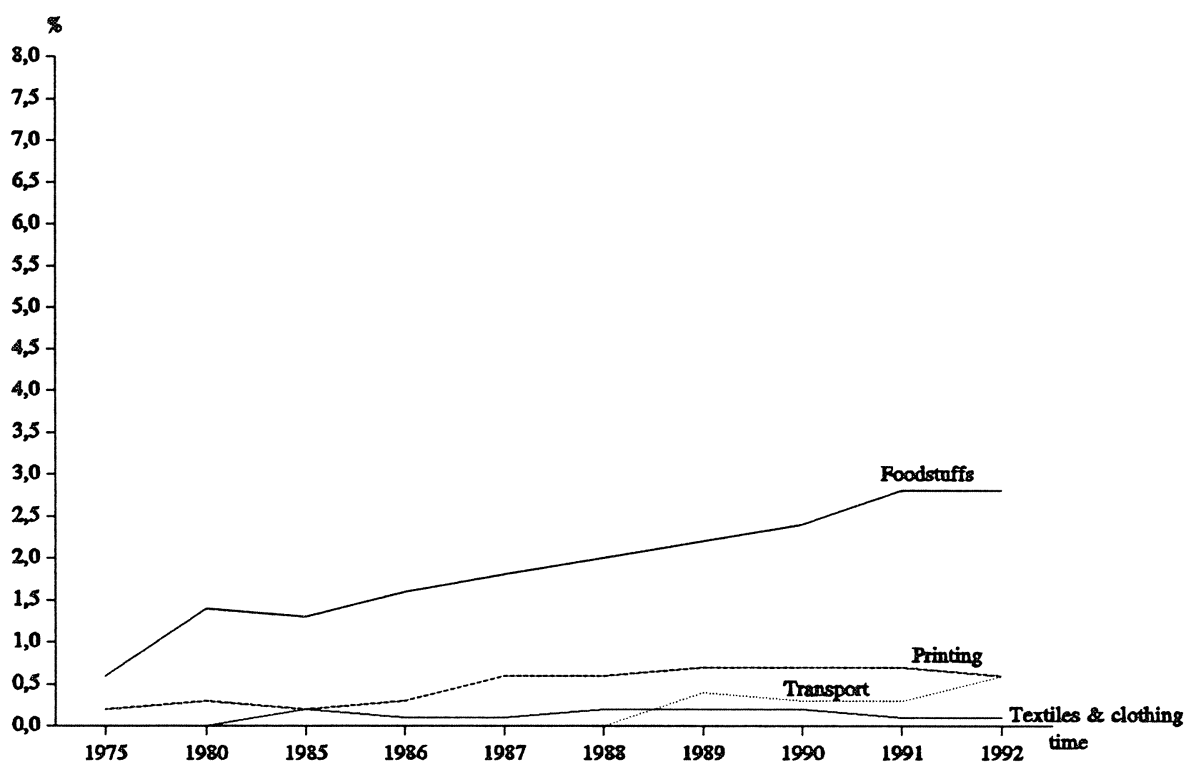

\subsection{New key indicators}

\subsubsection{Science and engineering degrees}

Table 7 presents one of the provisional OECD/CERI indicators. The indicator represents degrees awarded in natural science, in mathematics and computer science, and in engineering, as a percentage of all university-level degrees awarded. The natural sciences include astronomy, biology, chemistry and physics. The heading 'total science degrees' in the table cover the whole of natural sciences, mathematics and computer science, and engineering. The indicator measures the annual flow of people, trained in the different scientific disciplines, leaving the higher education system with a university-level degree. It should be noted that this indicator includes all university-level degrees, including the Ph.D. Also, the path leading up to a Ph.D. degree differs between countries: some award two degrees prior to the Ph.D., others only one. Moreover, some countries have a long cycle of studies before the initial degree can be obtained, and few possibilities for pursuing subsequent ones. The OECD points out that further investigation is needed to identify the influence which these differences in degree structures in higher education may have on comparisons between the OECD countries (OECD/CERI, 1992, pp. 102-104). 
Table 7. Degrees awarded in natural science, mathematics and computer science, and engineering as a percentage of total degrees awarded, 1988

\begin{tabular}{lrcrl}
\hline & $\begin{array}{l}\text { Natural } \\
\text { science }\end{array}$ & $\begin{array}{l}\text { Maths and } \\
\text { computer science }\end{array}$ & Engineering & $\begin{array}{l}\text { Total science } \\
\text { and engineering }\end{array}$ \\
\hline Netherlands & 8.3 & 1.4 & 15.1 & 24.8 \\
France & 10.4 & 7.7 & 21.6 & 39.6 \\
Germany & 7.8 & 2.8 & 18.7 & 29.3 \\
Italy & 6.2 & 3.2 & 6.5 & 15.9 \\
Belgium & 5.6 & 2.0 & 25.3 & 32.9 \\
Ireland & 14.1 & 2.6 & 12.3 & 26.9 \\
Denmark & 5.8 & 1.3 & 18.7 & 25.8 \\
Spain & 5.2 & 1.9 & 6.5 & 13.6 \\
Portugal & 5.2 & 1.0 & 17.5 & 23.6 \\
Austria & 4.5 & 5.5 & 8.2 & 18.2 \\
Switzerland & 13.4 & 3.0 & 8.4 & 24.8 \\
Norway & 3.3 & 1.3 & 10.8 & 15.5 \\
Sweden & 4.4 & 3.8 & 15.8 & 24.0 \\
Canada & 6.4 & 4.5 & 6.8 & 17.6 \\
United States & 5.5 & 4.8 & 8.7 & 19.0 \\
\hline
\end{tabular}

Source: OECD (1992)

Legend: Australia: natural science includes mathematics and computer science Japan: mathematics and computer science are included in engineering

The percentage of science and engineering degrees as a proportion of all degrees awarded ranges from 13.6 in Spain to 32.0 in Finland. The Netherlands, with $24.8 \%$, are in an intermediate position. In most countries, including the Netherlands, engineering degrees outnumber degrees awarded in natural science, and degrees in mathematics and computer science. However as far as university degrees awarded in mathematics and computer science are concerned, the Netherlands score extremely low.

\subsubsection{Labour market position of technically trained school-leavers}

Since 1991, ROA has carried out two national research projects among school-leavers in the Netherlands every year. The first project, called RUBS (Registration of the Outflow and Destination of School-leavers), is a nation-wide postal survey among school-leavers (whether as drop-outs or with qualifications) from general secondary education, and lower and intermediate vocational education in the Netherlands. The second research project, called the HBO-Monitor, is a nation-wide postal survey among graduates from all sectors of higher vocational education (excluding higher agricultural education) in the Netherlands. Both RUBS and the HBO-Monitor generate an up-to-date picture of the destination of last year's school-leavers and graduates, their labour market position, and the match between education and the labour market, differentiated by type of education and vocational specialisation. From these research projects, two indicators of the actual matching problems between technical education and the labour market are presented here. 
Table 8a. Unemployment rates" among Dutch school-leavers" about one year after leaving school, cohort 1989/90-1990/91

Cohort 1989/90

$\%$

Lower Technical Education

Total Lower Vocational Education

Intermediate Technical Education

Total Intermediate Vocational Education

Higher Technical Education" "*

Total Higher Vocational Education

\begin{tabular}{ll}
-- & 2 \\
-- & 4 \\
- & 3 \\
- & 4 \\
3 & \\
7 & 13 \\
& \\
\hline
\end{tabular}

Source: ROA

Legend: * Excluded school-leavers who are not available for the labour market

* Excluding drop-outs

* * Excluded universities

-- Not available

The first indicator, presented in table $8 a$, is the proportion of school-leavers who are still unemployed one year after leaving school. This gives an indication of quantitative bottlenecks (absorption problems) on the labour market for vocationally trained people (including technicians). The figures from table $8 a$ clearly indicate that school-leavers from lower and intermediate vocational education have less problems in finding a job than school-leavers from higher vocational education. The substantial increase in unemployment rates among schoolleavers from higher technical education indicates their dependence on the general level of activity in the economy.

The second indicator on the basis of RUBS and the HBO Monitor, presented in table $8 \mathrm{~b}$, deals with discrepancies in the labour market that may occur in the form of so called 'utilization problems', reflected in the degree of under-utilization, over-utilization, or incorrect utilization of the qualifications of employees, and in the effects this has on their productivity in the posts they hold. These problems arise when people occupy posts at a higher or lower level than their training prepared them for, or when the field of their training does not relate at all to their function (Van Dam, Ramaekers, \& Van der Velden, 1991, pp. 20-22). Respondents were asked what the minimum required educational level was for the functions they then occupied. If this is below their own educational level, this indicates competition with those educated at a lower level and may indicate under-utilization of their potential capacities. By contrast, if someone occupies a post above his own educational level, this indicates competition with those educated at a higher level and may indicate over-utilization of their potential capacities.

Table $8 \mathrm{~b}$ shows problems of under-utilization among school-leavers from (technical) vocational education. These are indicated by the percentage share of paid working school-leavers with jobs below their educational level. It can be seen that under-utilization among technically educated school-leavers is relatively low. Despite the fact that people with a non-technical educational 
background are more likely to accept jobs below their educational level (table $8 \mathrm{~b}$ ), unemployment rates for the two groups hardly differ (table 8a). This indicates the relatively strong labour market position of technically educated school-leavers.

Table 8b. Under-utilization " among Dutch school-leavers" about one year after leaving school, cohort $1989 / 90-1990 / 91$

Cohort $1989 / 90$

$\%$
Cohort 1990/91

$\%$
Lower Technical Education

Total Lower Vocational Education

Intermediate Technical Education

Total Intermediate Vocational Education

Higher Technical Education"**

Total Higher Vocational Education

$\begin{array}{ll}-- & 14 \\ -- & 23 \\ -- & 18 \\ -- & 22 \\ 12 & \\ & 13 \\ & 22\end{array}$

Source: ROA

Legend: * Proportion of paid working school-leavers having jobs below their educational level.

* Excluding drop-outs.

* Excluding universities.

- Not available

Besides the minimum required educational level for their current function, the respondents are asked to indicate which field of education was required for the function they occupy. If the field of their training does not relate at all to their function, this indicates that they are competing with persons educated in other fields of study and may even indicate incorrect utilization of their qualifications.

Table 8c. Incorrect utilization" among Dutch school-leavers " about one year after leaving school, cohort 1989/90-1990/91

Cohort $1989 / 90$

Cohort 1990/91

\begin{tabular}{lll}
\hline & $\%$ & $\%$ \\
Lower Technical Education & -- & 47 \\
Total Lower Vocational Education & -- & 60 \\
Intermediate Technical Education & -- & 31 \\
Total Intermediate Vocational Education & -- & 49 \\
Higher Technical Education* * & & 10 \\
Total Higher Vocational Education & 12 & 16
\end{tabular}

Source: ROA
Legend $*$ Proportion of paid working school-leavers, having jobs for which no specific or a completely different field of study is required.

* Excluding drop-outs.

* * Excluding universities.

-- Not available. 
At all educational levels, school-leavers from technical schools get jobs within their own educational domain more often than school-leavers from other vocational schools. Table $8 \mathrm{c}$ also shows that the importance of the field of education increases with the level of education. This indicates that more highly educated school-leavers, especially when they have followed a technical education, end up in those segments of the labour market where more specific qualifications are required and little competition is experienced from other fields of study.

From the above, it may be concluded that technically educated school-leavers have a relatively strong labour market position. Compared to other vocationally educated school-leavers they more often end up within their own educational domain and their capacities are less underutilized. Although school-leavers from non-technical vocational schools more often accept jobs below their educational level or outside their own occupational domain, unemployment rates hardly differ between the two groups.

On the basis of medium-term forecasts made by ROA of changes in employment levels, the replacement demand and the flow of school-leavers onto the labour market, the expected labour market prospects for the period 1993-1998 of technology-related types of education may be characterized as follows (Research Centre for Education and the Labour Market, 1993, pp. 7782):

\section{Preparatory Vocational Education, Technical}

The unemployment for Preparatory Vocational Education, Technical, is at present low, but employment is falling. Although the flows leaving the education system are also low, the fall in employment means that the expected labour market prospects for the coming years are moderate. These types of education do offer great flexibility since the employment is spread over very many occupations and very many business sectors.

\section{Intermediate Vocational Education, Engineering}

The unemployment among school-leavers from Intermediate Vocational Education, Engineering, lies at present close to the average unemployment among school-leavers. The expected labour market prospects are moderate. With this educational background, one is very flexible as regards being able to perform many different kinds of work. Employment is well spread over both business sectors and occupations.

\section{Intermediate Vocational Education, Non-medical Laboratory}

Unemployment for school-leavers from Intermediate Vocational Education, Non-medical Laboratory does not differ much from the average unemployment among school-leavers. Because of the low flows of students with this educational background entering the labour market, the labour market prospects for the coming years are expected to be good. Employment for workers with this education is spread over various business sectors, so that they are in this respect flexible. They are however very dependent in finding work in the occupational class of chemical engineers and laboratory workers. 
Higher Vocational Education, Engineering

At the moment Higher Vocational Education, Engineering suffers from high unemployment among its school-leavers, but the labour market prospects for the near future are expected to be good. Furthermore, those with this educational background can find places in very heterogeneous jobs in diverse business sectors, so they are not dependent on a specific occupation to find work.

\section{Higher Vocational Education, Non-medical Laboratory}

Although the unemployment rate for Higher Vocational Education, Non-medical Laboratory is at present high, for the coming years the labour market prospects are expected to be good. One advantage of this education is that it is not vulnerable to changes in employment levels in a particular business sector, but offers fairly easy options for switching to other sectors.

\section{Higher Vocational Education, Business Administration Technology}

Higher Vocational Education, Business Administration Technology is growing rapidly and the high student flows are matched by high demand. The expectation, however, is that this demand will increase less rapidly than the supply, with the net effect that the prospects will deteriorate. This is in part due to the fact that people with this, still recent, educational background have a low labour turnover. New types of education, in particular, have to establish their position on the labour market, in part by penetrating occupations in which people with that background have not previously worked. This process is difficult to predict. The employment which this education offers seems not to be very dependent on specific occupations or business sectors.

\section{University Education, Engineering}

Over the coming years very many jobs are expected to be created for graduates from University Education, Engineering. However, because students are showing considerable interest in this course, the labour market prospects are only reasonable. Although those with this educational background can only find work in a limited number of occupations and business sectors, there are enough switching opportunities to ensure that employment is not dependent on a single occupation.

\section{University Education in Mathematics and Natural Sciences}

Many new jobs will be created for those with University Education in Mathematics and Natural Sciences over the coming years, as a result of which the work prospects for this type of education are good. Although the people with this education depend for their employment on a number of specific occupations, their occupational options are reasonably wide.

The labour market prospects for technically educated people working as R\&D researchers are very good. In a survey commissioned by the Dutch Ministry of Economic Affairs (Berendsen, De Grip \& Willems, 1991, p. 3), ROA forecasts a great shortage of researchers in beta-sciences (mathematics and natural sciences, medical sciences, technical sciences and agricultural sciences). The expected shortages apply to all educational levels. In the period 2006-2010 the total shortage of researchers with higher education will have risen to 12,570 , or $13 \%$ of all 
researchers employed. The expected shortages are largest with respect to mathematics and natural science. Here the shortage amounts to $22 \%$ of all researchers in these fields.

Table 9. Supply shortage of beta-researchers, in absolute numbers and as percentage of the expected employment, 2006-2010

\begin{tabular}{lrr}
\hline & absolute & $\%$ \\
\hline Scientific education & $-5,250$ & -11 \\
- agricultural sciences & 200 & 6 \\
- maths and natural science & $-3,560$ & -22 \\
- technical sciences & -960 & -5 \\
- medical sciences & -930 & -9 \\
Higher vocational education & $-7,320$ & -16 \\
Intermediate education & $-4,970$ & -20 \\
\hline
\end{tabular}

Source: ROA

The expected shortages of researches may pose a serious threat to the future development of $R \& D$ activities, and hence to the technological position, the competitiveness and the economic growth of the Netherlands.

\subsubsection{R\&D personnel in the labour force}

The 'World competitiveness report 1993' describes the availability of R\&D personnel. Table 10 shows that the ratio of R\&D personnel to the total workforce is highest in Germany and Japan, both of which have 14.1 R\&D workers for every thousand people in the labour force. Although the United States have the most people employed in R\&D, their relative position is much weaker than in Japan and Germany. However, the United States has the second largest growth rate in R\&D personnel, after Japan. The decline in R\&D workers in the United Kingdom is remarkable. This country shows an annual compound growth rate of $-0.72 \%$. The Netherlands has an intermediate position among the countries mentioned, although it does have the third highest growth rate of R\&D personnel. This means that the position of the Netherlands in the Europe Union is slightly improving with regard to the availability of R\&D personnel, but that the Netherlands are loosing ground compared to the United States and Japan. Both as a portion of the labour force and in terms of growth, Japan is taking the lead more firmly every year in terms of R\&D personnel. The table also indicates that in the near future Japan could overtake the United States in terms of total numbers of R\&D personnel. 
Table 10. Availability of R\&D personnel in 1991

\begin{tabular}{|c|c|c|c|}
\hline & $\begin{array}{l}\text { R\&D personnel per } \\
1,000 \text { of the } \\
\text { labour force }\end{array}$ & $\begin{array}{l}\text { total R\&D } \\
\text { personnel } \\
\text { fte }\end{array}$ & $\begin{array}{c}\text { growth in R\&D } \\
\text { personnel } \\
\%\end{array}$ \\
\hline Netherlands & 9.90 & 68.2 & 2.43 \\
\hline France & 12.00 & 292.8 & 1.65 \\
\hline Germany & 14.10 & 429.0 & 2.18 \\
\hline United Kingdom & 9.80 & 277.8 & -0.72 \\
\hline Sweden & 11.90 & 54.2 & 2.14 \\
\hline Austria & 6.70 & 23.1 & 2.74 \\
\hline United States & 7.69 & 949.2 & 2.85 \\
\hline Japan & 14.10 & 899.3 & 3.42 \\
\hline
\end{tabular}

Source: IMD

Legend: ". Annual compound percentage 1983-1991

$\because \times 1,000$

\subsubsection{Expenditure on education}

Expenditure on education as a percentage of GDP can be seen as a measure of the national support for education. Table 11 shows that public expenditure on education differs quite markedly from country to country. On average, countries are prepared to spend more than $5 \%$ of their GDP on education: only Japan and Germany spent less. However, in interpreting these figures one has to be very careful as some countries' expenditures for tertiary education include substantial public subsidies for student living expenses, whereas other countries' expenditures do not. ${ }^{5}$ For the Netherlands we know that expenditure on higher education does include student living expenses, thus the position of the Netherlands is less favourable than the table suggests. However, Dutch expenditures on education were clearly higher than in Japan.

5. OECD (1993), Education at a glance, p. 65. 
Table 11. Public expenditure on education as a percentage of GDP in 1991

\begin{tabular}{lcc}
\hline & $\begin{array}{c}\text { total } \\
\text { expenditure } \\
\%\end{array}$ & $\begin{array}{c}\text { expenditure on } \\
\text { higher education } \\
\%\end{array}$ \\
\hline Netherlands & 5.6 & 1.7 \\
France & 5.4 &..- \\
Germany" & 4.0 & 0.9 \\
United Kingdom & 5.3 & 1.0 \\
Sweden & 6.5 & 1.2 \\
Austria & 5.4 & 1.1 \\
United States & 5.5 & 1.4 \\
Japan & 3.7 & 0.3 \\
OECD total & & 1.2 \\
\hline
\end{tabular}

Source: OECD

Legend: "Tertiary education (ISCED 5 or higher)

" Federal Republic of Germany

--- Not available

However, when looking at the public expenditures per capita on education (table 12), we get a quite different view. This table suggest that the Netherlands, along with Germany and the United Kingdom, spend relatively little on education. The large sums per capita spent in Sweden and the United States are most remarkable, and the relatively high spending of Japan is quite surprising. Although we have to be careful in interpreting this table, it suggests that the United States, and to a lesser degree Japan, are prepared to invest more in education than certain European countries, including the Netherlands.

Table 12. Public expenditure per capita on education in 1991

\section{expenditure \\ per capita \\ US \$}

Netherlands

France

Germany"

United Kingdom

Sweden

Austria

United States

Japan
971

1,139

795

691

2,001

1,099

1,517

1,111

Source: IMD

Legend: " Federal Republic of Germany 


\subsubsection{Skill-level of the population}

Table 13 shows the percentage of national populations aged 25 to 64 who have completed higher education. This is an indicator of the availability of highly skilled workers who are essential for technological development. The table indicates increasing levels of people with higher education in most countries. Only France shows a decrease in the proportion of higher skilled since 1989. Most remarkable in this table is the very high proportion of people with higher education in the United States, 13 percentage points above its nearest rival. Compared to the other European countries, the Netherlands take an average position, after Sweden and Germany, but above France and the United Kingdom.

Table 13. Percentage of the population aged 25 to 64 years who have completed higher education"

\begin{tabular}{|c|c|c|}
\hline & $\begin{array}{c}1989 \\
\%\end{array}$ & $\begin{array}{c}1991 \\
\%\end{array}$ \\
\hline Netherlands" & 19 & 20 \\
\hline France & 17 & 15 \\
\hline Germany & 17 & 22 \\
\hline United Kingdom & 16 & 16 \\
\hline Sweden & 23 & 23 \\
\hline Austria & 5 & 7 \\
\hline United States & 35 & 36 \\
\hline Japan " " & 22 & \\
\hline
\end{tabular}

Source: OECD

Legend: "tertiary education or higher (ISCED 5 and higher)

* 1990

\#. 1987

\#*: not available 


\section{INCIDENTAL SURVEYS}

\subsection{Expenditure on education}

\subsubsection{Public expenditure on higher education in the EU}

The Task Force on Human Resources, Education, Training and Youth of the European Commission has commissioned the Center for Higher Education Policy Studies of the University of Twente to carry out a comparative study of expenditure on higher education in the EU member states (Kaiser, et al., 1992). In this study four indicators have been selected:

1. total public expenditure on higher education as a percentage of GDP;

2. total public expenditure on higher education as a percentage of total public expenditure;

3. total public expenditure on higher education as a percentage of the national education budget;

4. public expenditure per student.

In comparing public expenditure on eduction between countries, international differences in methods of public accounting, differences in national statistics and the variety in national higher education systems give rise to a number of 'conceptual biases'.

Because of the diversity of the data needed and the complexity of the field of study, three methods for data collection were used:

- assessment and examination of existing sources of information;

- development and application of a questionnaire;

- consultations with national experts.

Table 14a gives an overview of the level of public expenditure on higher education in 1987. With respect to the first three indicators, the results show that higher education expenditure is highest in the Netherlands and Denmark. The extremely low figures for Luxembourg are due to the specific characteristics of its higher education system. The level of expenditure per student, both in the university sector and in the non-university sector, is very high in the Netherlands and Denmark. It can also be seen that in countries which do not have a formal binary higher education system, the expenditure per student in the non-university sector is higher than it is in the university sector. In countries that have a truly binary higher education system (Belgium, Germany, the Netherlands, and - until recently - the United Kingdom), on the other hand, the expenditure per student is higher in the university sector than in the non-university sector (Kaiser, et al, 1992, p. 133). 
Table 14a. Level of public expenditure on higher education, 1987

\begin{tabular}{|c|c|c|c|c|c|}
\hline & $\begin{array}{l}\text { as } \% \\
\text { of GDP }\end{array}$ & $\begin{array}{l}\text { as } \% \\
\text { of public } \\
\text { expenditure }\end{array}$ & $\begin{array}{l}\text { as } \% \text { of } \\
\text { education } \\
\text { budget }\end{array}$ & $\begin{array}{l}\text { expenditure } \\
\text { university }\end{array}$ & $\begin{array}{l}\text { per student } \\
\text { non-university }\end{array}$ \\
\hline Netherlands & 1.9 & 4.2 & 25.4 & 4542 & 4260 \\
\hline France & 0.7 & 1.3 & 12.2 & 2845 & 5773 \\
\hline Germany & 0.9 & 1.8 & 23.6 & 3325 & 2283 \\
\hline U.K. & 0.8 & 1.9 & 16.6 & 4016 & -- \\
\hline Italy & 0.5 & 1.2 & 19.6 & 3105 & --- \\
\hline Belgium & 1.0 & 2.6 & 20.3 & 3786 & $2428^{b}$ \\
\hline Luxembourg & 0.2 & 0.3 & 4.2 & 6565 & 16853 \\
\hline Ireland & 1.2 & 2.0 & 20.6 & 3379 & 4204 \\
\hline Denmark & 1.5 & 2.5 & 25.8 & $6031^{c}$ & $8297^{c}$ \\
\hline Greece & 0.7 & 1.9 & 23.9 & 1587 & 1029 \\
\hline Portugal & 0.7 & 2.0 & 18.5 & 1967 & 2685 \\
\hline Spain & 0.5 & 1.3 & 16.2 & 808 & --- \\
\hline EU & 0.8 & 2.1 & 18.6 & 2735 & 3738 \\
\hline
\end{tabular}

Source: Kaiser, et al., 1992, p. 133, 223, 224, 227;

Legend: a Current prices in ECU, not including public expenditure on student support.

b 1985

c 1986

-- Not available

It should be noted that the German higher education system has some characteristics that make it both similar to and different from that of other systems in Europe. Like many other European systems, Germany has a binary system consisting of a university and a non-university sector. In contrast to other systems, however, it is a federal system in which the main thrust of legislation and financial regulations is at the state (Länder) level. In this sense, it could be said that Germany has several different higher education systems (Kaiser, et al., 1992, p. 57).

Table 14b gives an overview of changes in the four indicators during the period 1980-1987. These figures clearly show the substantial decrease in the Netherlands in expenditure on higher education as a percentage of GDP, as a percentage of total public expenditure and as a percentage of the national education budget. In Luxembourg, Spain and Portugal, on the other hand, there have been strong increases for all three indicators. The general conclusion (Luxembourg excluded) with respect to the first three indicators is that the differences between the 'high spending' EU member states (the Netherlands and Denmark) and the 'low spending' EU member states (Italy, Spain and France) are becoming smaller. 
Table 14b. Changes in public expenditure on higher education, 1980-1987 (in percentages)

\begin{tabular}{|c|c|c|c|c|c|}
\hline & $\begin{array}{l}\text { as } \% \\
\text { of GDP }\end{array}$ & $\begin{array}{l}\text { as } \% \\
\text { of public } \\
\text { expenditure }\end{array}$ & $\begin{array}{l}\text { as } \% \text { of } \\
\text { education } \\
\text { budget }\end{array}$ & $\begin{array}{l}\text { expenditure } \\
\text { university }\end{array}$ & $\begin{array}{l}\text { per student } \\
\text { non-university }\end{array}$ \\
\hline Netherlands & -19 & -28 & -13 & -25 & -18 \\
\hline France & 1 & -10 & 0 & $-3^{d}$ & $10^{\mathrm{d}}$ \\
\hline Germany & -13 & -11 & 3 & -24 & -40 \\
\hline United Kingdom & -170 & -7 & -3 & -9 & --. \\
\hline Italy & 36 & 11 & 43 & 48 & -- \\
\hline Belgium & -11 & -6 & 1 & -20 & $-28^{b}$ \\
\hline Luxembourg & 133 & 182 & 154 & 82 & 386 \\
\hline Ireland & 9 & 0 & -1 & -19 & -31 \\
\hline Denmark & 1 & -2 & $25^{c}$ & $-8^{c}$ & $33^{c}$ \\
\hline Greece & 63 & 7 & 27 & 2 & -28 \\
\hline Spain & 43 & 17 & 3 & 14 & -- \\
\hline Portugal & 53 & 27 & 41 & 28 & 154 \\
\hline EU & -5 & 13 & 0 & & \\
\hline
\end{tabular}

Source: Kaiser, et al., 1992, p. 134

Legend: a Based on national currencies and constant prices

b $\quad 1980-85$

c $\quad 1980-86$

d $\quad 1983-87$

e $\quad 1981-87$

--- Not available

With respect to changes in public expenditure per student during the period 1980-87, the general conclusions are that the university sector shows a clear process of convergence between the 'high spending' and 'low spending' EU member states, but that the developments in the non-university sector are more diverse. Secondly, the differences in expenditure per student between the university and non-university sector are becoming smaller. This can be called a process of convergence within the EU member states (Kaiser, et al., 1992, pp. 132135).

\subsubsection{Public expenditure on labour market training}

From table 15 it can be seen that public expenditure on training unemployed adults and employed adults who are threatened with redundancy is highest in Denmark, Germany and Ireland, with the Netherlands taking a position between the 'high spending' and 'low spending' EU member states. 
Table 15. Training for unemployed adults and those threatened by redundancy as a percentage of GDP

\begin{tabular}{ll} 
Netherlands & 0.22 \\
France & 0.28 \\
Germany & 0.44 \\
United Kingdom & 0.15 \\
Italy & 0.003 \\
Belgium & 0.13 \\
Luxembourg & 0.02 \\
Ireland & 0.31 \\
Denmark & 0.45 \\
Greece & 0.04 \\
Spain & 0.07 \\
Portugal & 0.01 \\
EU & \\
\hline
\end{tabular}

Source: Auer, 1993, p. 22

Legend: Figures for Belgium, France and the Netherlands are for 1990

Figures for the UK do not include Northern Ireland.

\subsubsection{Expenditure on continuing vocational training}

In 1992 the Task Force Human Resources published the Synoptic Tables Report for the first time. This contains information on continuing vocational training in the European Union. However, the data is not in all respects comparable, as every member state of the European Union still has its own definitions and ways of calculating. Having said this, table 16 shows that in most countries between $1 \%$ and $2 \%$ of the wage bill is spent on continuing vocational training, with the rate in France being relatively high, and that in Greece being relatively low.

Table 16. Percentage of the wage bill spend on continuing vocational training in 1990

wage bill

$\%$

\begin{tabular}{lr} 
Belgium & 1.40 \\
France & 3.14 \\
Greece & 0.67 \\
Ireland" & 1.80 \\
Netherlands" & 1.70 \\
Portugal & 1.10 \\
\hline
\end{tabular}

Source: Task Force Human Resources of the European Union

Legend: " 1989

* wage mass

\subsection{Participation in training by occupational sector}

Employers can seek to satisfy rising skill requirements by demanding higher skills of new employees (recruitment policy) and by having their current labour force in additional training 
(training policy). An indication of the importance of training policies in the various occupational sectors of some member states of the European Union is presented in tables $17 \mathrm{a}$ and $17 \mathrm{~b}$. Participation in training, as presented in table $17 \mathrm{a}$, refers to all kinds of training related to economic activity. This means that attending a school which provides training in specific subjects, in-company training, 'dual' training forms (a combination of vocational education and in-plant training) and apprenticeships are included.

Table 17a. Participation in training by occupational sector in 1991 for some member states of the European Union

ISCO’68

$\begin{array}{ccccccc}\text { B } & \text { D } & \text { F } & \text { FRG } & \text { NL } & \text { UK } & \text { EU } \\ \% & \% & \% & \% & \% & \% & \%\end{array}$

Professional, technical and

related workers

Administrative and managerial workers

$3.7 \quad 23.3$

7.9

$10.5 \quad 23.1$

26.6

14.2

Clerical and related workers

$1.9 \quad 17.4$

2.4

$4.9 \quad 13.9$

14.8

9.4

Sales workers

$2.4 \quad 31.9$

4.3

9.125 .5

$17.2 \quad 10.5$

Service workers

$\begin{array}{lll}1.7 & 25.4 & 4 .\end{array}$

$\begin{array}{llll}9.2 & 24.0 & 17.9 & 9.8\end{array}$

Agricultural, animal husbandry and forestry

workers, fishermen and hunters

$\begin{array}{lllllll}1.1 & 16.8 & 1.3 & 6.3 & 14.0 & 9.8 & 3.3\end{array}$

Production and related workers, transport

equipment operators and labourers

$\begin{array}{lllllll}1.8 & 19.4 & 3.1 & 8.7 & 16.6 & 10.2 & 6.7\end{array}$

Total

$2.4 \quad 22.7$

$\begin{array}{llll}4.2 & 9.0 & 21.2 & 16.3\end{array}$

9.2

Source: Eurostat/ROA

Legend: "Italy is excluded

Table 17a shows large differences in participation in training between both countries and occupational sectors. The United Kingdom, the Netherlands and Denmark are the leading countries in training activities. Training activities in Belgium and France are remarkably low.

The differences in participation between occupational sectors are also very large. In particular, the labour force employed in the occupational sector of 'professional, technical and related workers' has a high rate of participation in training. Approximately one out of seven workers employed in this occupational sector in the European Union participates in training, whereas only one out of thirty workers employed in the occupational sector of 'agricultural, animal husbandry and forestry workers, fishermen and hunters' participates in training.

Once again, differences between countries are large. Denmark and the Netherlands show high training participation rates for all occupational sectors. The rates in both countries for 'agricultural, animal husbandry and forestry workers, fishermen and hunters', in particular, are high when compared to the European average. Belgium has low training participation rates for all occupational sectors.

Table 17b charts the change in training participation rates from 1987 to 1991 . For the European Union as a whole, it can be seen that training participation rates have increased in all 
sectors, except for the occupational sector of 'production and related work, transport equipment operators and labourers'. In this light it is very remarkable that in Belgium and the Federal Republic of Germany total participation in training actually decreased. Although in the Netherlands the proportion of 'professional, technical and related workers' participating in training decreased by 0.5 percentage points, the total participation rate increased by 2 percentage points. This high increase has mainly been caused by the occupational sectors of 'sales workers' and 'service workers', with increases of 5.2 and 4.3 percentage points, respectively. The United Kingdom exhibits the largest increase in the proportion of workers participating in training, with a rise of 2.9 percentage points. The sectors responsible for this large increase are 'professional, technical and related workers', 'clerical and related workers' and 'service workers'. The results for Denmark are remarkable too. Whereas the occupational sectors of 'service workers' and 'production and related workers' show decreases of 0.1 and 0.6 percentage points, respectively, the occupational sectors of 'administrative and managerial workers' and of 'agricultural, animal husbandry and forestry workers, fishermen and hunters' experienced increases in their rates of 5.5 and 5.7 percentage points respectively (Hoevenberg \& De Grip, 1994).

Table 17b. Percentage-points change in participation in training by occupational sector for some member states of the European Union for the period 1987-1991

ISCO’68

$\begin{array}{ccccccc}\text { B } & \text { D } & \text { F } & \text { FRG } & \text { NL } & \text { UK } & \text { EU* } \\ \%- & \%- & \%- & \%- & \%- & \%- & \%- \\ \text { points } & \text { points } & \text { points } & \text { points } & \text { points } & \text { points } & \text { points }\end{array}$

Professional, technical and

related workers

Administrative and managerial workers

Clerical and related workers

Sales workers

Service workers

$-0.2$

$-1.1$

$-0.4$

$-0.4$

$-0.5$

Agricultural, animal husbandry and forestry

workers, fishermen and hunters

Production and related workers, transport

equipment operators and labourers

$\begin{array}{ccccccc}0.5 & 5.7 & -0.5 & -1.0 & 2.2 & 1.0 & 0.0 \\ -0.5 & -0.6 & -0.2 & -1.0 & 1.0 & 1.3 & -0.1 \\ -0.4 & 0.7 & 0.0 & -0.8 & 2.0 & 2.9 & 0.6\end{array}$

Source: Eurostat/ROA

Legend: "Italy is excluded

\subsection{Social support for technological progress}

The social support for technology is of great importance for the diffusion of technological knowledge because this knowledge penetrates deeper into a society which is interested in technology. This applies, however, not only to social awareness of the advantages and opportunities of new technology but also to awareness of its disadvantages and risks. Besides, the return on R\&D investments increases if an interchange is possible between the producers of new technological knowledge and a market with an innovatory attitude (Minne, 1992, pp. 89). 
Tables $18 \mathrm{a}$ and $18 \mathrm{~b}$ present some of findings from a 1989 survey, in the framework of the Eurobarometer, which contained questions regarding the social support in Europe for technological progress.

Table 18a. Social interest in discoveries, "in selected EU member states (1989)

\begin{tabular}{lcc} 
& $\begin{array}{c}\text { Medical discoveries } \\
\%\end{array}$ & $\begin{array}{c}\text { Scientific discoveries } \\
\%\end{array}$ \\
\hline Netherlands & & 45 \\
France & 59 & 52 \\
Germany & 61 & 24 \\
United Kingdom & 32 & 36 \\
Belgium & 42 & 28 \\
EU & 35 & 35 \\
\hline
\end{tabular}

Source: European Commission, Directorate-general of Sciences, Research and Development (1990), De Europeanen, wetenschap en technologie, based on the March/April 1989 survey in the framework of the Eurobarometer, in: Minne, 1992, p. 90.

Legend: * Percentage of interviewees who are highly interested

Table 18a clearly shows that, in comparison with other EU member states, the Dutch population has a highly innovatory attitude. However, from table $18 \mathrm{~b}$, it can be observed that in the Netherlands there is a great deal of mistrust of the blessings of technology and the appropriateness of the decisions of scientists (Minne, 1992, pp. 89-90).

Table 18b. Social attitude towards science and technology, "in selected EU member states (1989)

\begin{tabular}{|c|c|c|c|c|c|c|c|c|}
\hline & $\begin{array}{l}A \\
\%\end{array}$ & $\begin{array}{l}\text { B } \\
\%\end{array}$ & $\begin{array}{l}\mathrm{C} \\
\%\end{array}$ & $\begin{array}{l}\text { D } \\
\%\end{array}$ & $\begin{array}{l}E \\
\%\end{array}$ & $\begin{array}{l}F \\
\%\end{array}$ & $\begin{array}{l}\mathbf{G} \\
\%\end{array}$ & $\begin{array}{l}\mathbf{H} \\
\%\end{array}$ \\
\hline Netherlands & 87 & 75 & 59 & 30 & 42 & 38 & 23 & 26 \\
\hline France & 91 & 76 & 58 & 57 & 45 & 36 & 42 & 19 \\
\hline Germany & 53 & 74 & 53 & 35 & 38 & 36 & 29 & 24 \\
\hline U.K. & 82 & 76 & 51 & 42 & 44 & 29 & 24 & 28 \\
\hline Belgium & 70 & 69 & 53 & 42 & 35 & 41 & 39 & 28 \\
\hline EU & 74 & 73 & 58 & 46 & 46 & 37 & 34 & 24 \\
\hline
\end{tabular}

Source: European Commission, Directorate-general of Sciences, Research and Development (1990), De Europeanen, wetenschap en technologie, based on the March/April 1989 survey in the framework of the Eurobarometer, in: Minne, 1992, p. 90.

Legend: * Percentage of interviewees who agree with the proposition:

A Even if no direct results are generated, government should finance scientific research

B Science and technology make life easier, more comfortable and improve health

C Science changes our life too fast

D The positive effects of science are more important than the damaging effects

E Too much emphasis is put on science and too little on religion

F Having scientific knowledge is not important in my daily life

G One can rely on the appropriateness of scientists' decisions

$\mathrm{H}$ Computers and computerization's net effect is to create more employment 
In the context of the research programme Technology and Society of the Dutch Ministry of Economic Affairs, ROA has examined the social support for technological progress among young people in the Netherlands (Willems and De Grip, 1993). In this research project three dimensions were distinguished:

1. value judgements on technological developments;

2. the image of technical education and work;

3. intentions for educational and vocational choices with respect to technology.

Over 2000 pupils in secondary education were surveyed in the autumn of 1992 by means of a written questionnaire.

Apart from separate analyses of these three elements, the relation between the elements was also examined. Moreover, the various aspects of the image of technical education and work were compared to information on the current situation. This made it possible to detect bottlenecks which policies aimed at stimulating technical education would have to overcome.

\section{Value judgements on technological developments}

With respect to value judgements regarding technology, three dimensions were distinguished: interest in technology, technology assessment, and the role of women in technology. It was found that boys are generally highly interested in technology, and girls generally had hardly any interest. In general young people have a positive opinion regarding the consequences for society of technological progress, with girls being somewhat more critical than boys in this respect. In particular, their assessment of the social consequences is more negative. Both boys and girls have a predominantly positive attitude to women's role in technology. The attitude of youngsters belonging to minority ethnic groups is much more negative in this respect.

\section{Image of technical education and work}

Technical studies have the image of being difficult. Especially girls and minority ethnic groups think that technical studies are difficult, as compared to other types of education. By contrast, the pupils' image of the labour market position of technically trained people is predominantly positive. Their chance of getting a job and their income are thought to be relatively high. Girls think somewhat less positively about the labour market position of technically trained people than boys. Most pupils have a rather 'traditional' opinion of technicians' working conditions. The work is thought to be heavy and occasionally dirty. By contrast, pupils think that the psychological strain is rather low, as is the risk of the work being dull. In addition, technicians are thought to be rather independent in executing their tasks. In general the pupils are rather well-informed about the actual labour market situation of technically trained people. However, their image of their working conditions is on the whole too negative, as compared to reality, especially in respect of the image of technical work being heavy and dirty.

\section{Intentions of choosing a technical study or job}

The choice of technical studies can be described in a funnel-shaped model, in which a narrowing in the supply of young people for technical work takes place at three moments. The first narrowing is at the end of primary education. A small percentage of boys and a rather substantial proportion of girls choose, at the age of 12 , for non-technical preparatory vocational 
education. The second narrowing takes place in general secondary education when pupils, at the age of about 15, must choose the subjects in which they are to be educated. Here many pupils (especially girls) drop one or more of the hard sciences. A third narrowing takes place at the end of secondary education when, at the age of 16 to 18 , pupils make their more or less definite choice of a vocation or a kind of tertiary education. The research findings show that hardly a quarter of the pupils intend to choose technical work or a technical education (figure 1).

Willems and De Grip presented their research findings at the sixth international PATT conference. PATT is the acronym for Pupils' Attitude Towards Technology. PATT has served since 1985 as an international platform for discussion about technology education. The theme of the sixth PATT conference was 'Technology Education and the Environment', with four subthemes:

- environmental issues in primary and secondary education;

- pupils' attitudes towards technology and the environment;

- gender and philosophical aspects of environmental issues in technology education;

- environmental issues in the education of technology teachers.

However no new relevant and current data was presented with respect to these sub-themes.

Figure 1. The choice funnel for technical education or work

Boys

Girls

$100 \%$

$100 \%$

$91 \%$

Choice of technical preparatory vocational education after primary education

$51 \%$

Technical subjects chosen in general secondary education

Choice of technical education or technical work

$44 \%$

Choice of technical fields

$24 \%$

Source: Willems and De Grip (1993), p. 96. 


\section{INITIATIVES FOR GENERATING NEW INDICATORS}

\subsection{International Education Indicators}

In 1988 the Centre for Educational Research and Innovation (CERI) of the OECD started a project on International Indicators and the Evaluation of Educational Systems, called the INES Project (OECD/CERI, 1991). The project is organised in four networks, which work on indicators concerning:

- outcomes of education;

- education and labour market destinations;

- features of schools;

- attitudes and expectations.

The first set of international education indicators developed by CERI was presented in the CERI/OECD publication of 1992: Education at a Glance. The OECD framework consists of three clusters of education indicators, offering information on:

1. the demographic, economic and social contexts of education systems;

2. features of education systems;

3. outcomes of education.

Within each cluster, several indicators have been proposed and methodologies for measuring them have been developed. The 1992 publication presents only the realised indicators for the school year 1988. The full set will be described in the forthcoming INES Handbook.

With the publication of Education at a glance, the INES project on International Education Indicators has entered a new phase. The main aim now is to develop the infrastructure, procedures and methods that will be needed if the indicators are to become part of the OECD's routine system for collecting, calculating and reporting statistical information on economic and social trends in member countries (OECD, 1992, pp. 15-16). Some of the results from OECD's 1992 report Education at a Glance are presented in chapter 2 and 3 of this report. 
Figure 2. International education indicators proposed by the OECD

1 Indicators of demographic, economic and social context

A Demographic factors:

- general educational attainment

- gender differences in education

- labour force participation and unemployment

- youth and population

$B$ Economic factors:

- GDP per capita

2 Indicators of features of education systems

A Expenditure on education:

- expenditure on education as a percentage of GDP

- expenditure on education as a percentage of total public expenditure

- shares of educational expenditure

- sources of public expenditure on education"

- current and capital expenditure

- expenditure per student

- national effort in education

- relative expenditure per student

$B$ Human resources:

- staff employed in education"

- pupil-teacher ratio

C Participation and student flows:

- participation in formal education

- pre-compulsory effort

- upper secondary education

- entry ratio to tertiary education

- non-university tertiary education

- university education

D Decision-making characteristics:

- locus of decision-making"

- decision-making by schools"

- domains of decision-making"

- modes of decision-making

- school autonomy in decision-making

3 Indicators of outcomes of education

A Educational attainment:

- upper secondary completion

- higher education graduation

- higher education survival"

- science and engineering degrees

- science and engineering effort"

$B$ Learning outcomes:

- mathematics achievement

- school differences in achievement"

- student differences in achievement

C Status after schooling:

- unemployment and education

- earnings and education

Source: OECD (1992), p. 13

Legend: Provisional indicators, considered experimental because of disagreement as to their validity and applicability or because they were measured using data that was not specifically collected for this purpose. 


\subsection{Synoptic tables on continuing vocational training}

The synoptic tables summarize the latest information available in the twelve member states on Continuing Vocational Training (CVT) for company employees (Commission of the European Union, 1993, pp. 4-9). The tables are prepared by the Task Force for Human Resources, Education, Training and Youth of the Commission of the European Union. In 1991 it was decided that the tables would be regularly updated. In 1992 the synoptic tables contained, for the first time, complete data from all twelve member states. The selected indicators in the tables are qualitative or quantitative. The qualitative ones provide information on the measures specifically designed to improve either investments by firms in training or the access of their employees to it. The quantitative indicators give the figures in the different countries which are used to measure the training effort. The tables contain the following 10 indicators:

- legal framework or agreements with respect to rights on CVT;

- current changes in the field of CVT;

- training plans;

- specific measures on access for employees;

- supply, coherence and evaluation of CVT;

- new forms of partnerships;

- specific CVT measures for SMEs;

- persons covered by CVT;

- financing of CVT;

- expenditure on CVT.

The synoptic presentation of the information does not mean that the data from various countries is comparable. Hence, a brief description of the training systems of the EU member states, and definitions of the key concepts of CVT relating to these systems, supplement the tables to facilitate understanding and interpretation. In section 3.1.3. the indicator relating to expenditure on CVT is presented.

The synoptic tables will be supplemented by other work in progress in the framework of EU's FORCE programme (Formation Continue en Europe):

- the Managing Chart on Continuing Vocational Training, which should allow comparisons to be made between the existing quantitative data and information on CVT in the different EU member states;

- the Eurostat survey on Continuing Vocational Training in companies, which will collect homogeneous quantitative and qualitative data on target groups, costs and arrangements for training employees;

- the national reports on CVT and its financing. 


\section{CONCLUSIONS}

\section{Key indicators}

It has not yet been possible to update some of the key indicators on the position of the Netherlands with regard to the implementation of technology, since the necessary input data is not yet available. The findings with respect to the Netherlands from the indicators updated so far can be summarized as follows.

1. A declining share of technically educated students in the classes of school-leavers in the 1990s, reducing the share of the technically educated in the potential labour force, and thus eroding the Netherlands' future scientific and technological breeding ground in terms of innovation as well as diffusion.

2. A still tight labour market situation for vocationally trained school-leavers (including technicians), educated at lower and intermediate level, indicating a growing need for training to overcome present or possible future impediments to the further diffusion of technological progress. At the moment there is no shortage of school-leavers from higher (technical) vocational education.

3. A declining proportion in the active population of the 15-24 year age bracket, indicating a decreasing ability to respond to the changed educational requirements due to technological progress (since adjusting initial education will have less effect as the proportion of young people in the labour force falls);

4. A high and growing proportion of students in vocational education especially at the third level, indicating that people should be open to technological progress in their later careers to a high degree.

\section{Incidental surveys}

The Netherlands is one of the countries in which public expenditure on higher education is very high. The level of expenditure per student, both in the university sector and in the nonuniversity sector, is also very high in the Netherlands. However, between 1980 and 1987, there was a substantial decrease in Dutch expenditure on higher education as a percentage of GDP, as a percentage of total public expenditure and as a percentage of the national education budget. As a result the differences between the 'high spending' EU member states (the Netherlands and Denmark) and the 'low spending' EU member states (Italy, Spain and France) became smaller. In another survey it was found that in the Netherlands training policies (indicated by the increasing participation in training) are becoming more important. As far as public expenditure on training unemployed adults and those threatened by redundancy is concerned, the Netherlands score is only average.

Social support for technology is of great importance for the diffusion of technological knowledge. Although, in comparison with other EU member states, the Dutch population has a highly innovatory attitude, a great deal of mistrust of the blessings of technology and the appropriateness of the decisions of scientists can be observed in the Netherlands. In a survey among 2000 Dutch pupils in secondary education it was found that technical education has the 
image of being difficult compared to other types of education. In addition, pupils have a very negative image of the working conditions of technicians. Although pupils' image of the labour market position of technically trained people is predominantly positive, hardly a quarter of the pupils intend to choose technical work or a technical education.

However, the participation in technical vocational education is declining, both in regular education and in dual-system education. This development may lead to shortages of technically educated, especially at the secondary level. The low level of under-utilization among technically educated schoolleavers, as compared to non-technically educated schoolleavers, and the good labour market prospects of R\&D personnel, are illustrative in this respect.

In general it can be said that the Dutch labour force has a high degree of open-mindedness towards technological progress. However, the position of the Netherlands in generating technological progress is becoming vulnerable as a result of the declining participation in (initial) technical education, which may find its cause in the negative image Dutch pupils have of technical education and work, and the declining proportion of the 15-24 age bracket in the population.

\section{Network mailing and the integration of data collection}

Like last year, this year's mailing to our peer network (intended for the collection of additional, internationally comparable, data) has produced less immediate 'hits' than the first year. The results are described in appendix 3 . Since international cooperation in the collection of data entails adapting data files to international standards, international organizations such as Eurostat, the OECD and UNESCO can still provide little detailed, internationally comparable, data. Nevertheless, there have been some important new developments in integrating data collection in order to make national data internationally comparable. These initiatives deal with indicators of the implementation of technology in general, of compulsory education, and continuing vocational education. Our participation in the STEMMING project should therefore remain focused on the developments in such initiatives and on any relevant international publications. 


\section{ABBREVIATIONS}

CBS : Centraal Bureau voor de Statistiek (Dutch Central Bureau for Statistics)

CEDEFOB : European Centre for the Development of Vocational Training

CERI : Centre for Educational Research and Innovation

CPB : Centraal Plan Bureau (Dutch Central Planning Bureau)

CORO : Centraal Orgaan Regionale Organen leerlingwezen (Dutch Central Organ of the Regional Organs, i.e., apprenticeship supervisory boards)

EU : European Union

Eurostat : European Bureau for Statistics of the European Union

IAB : Institut für Arbeitsmarkt- und Berufsforschung der Bundesanstalt für Arbeit

IEA : International association for the evaluation of Educational Achievement

ILO : International Labour Organisation

MERIT : Maastricht Economic Research institute on Innovation and Technology

MOW : Ministerie van Onderwijs en Wetenschappen (Dutch Ministry of Education and Science)

OECD : Organisation for Economic Co-operation and Development

ROA : Researchcentrum voor Onderwijs en Arbeidsmarkt (Research Centre for Education and the Labour Market)

UNESCO : United Nations Educational Scientific and Cultural Organisation 


\section{SOURCES}

Auer, P. (1993), Continuing Training for the Employed in Europe, in: Employment Observatory Policies, no. 42, pp. 21-26.

Brandsma, T.F., J.W. van Dam, A. de Grip (1992), Continuing vocational training in the Netherlands, Managing Chart, Enschede, Maastricht.

Centraal Bureau voor de Statistiek ("), Statistiek van het beroepsonderwijs, Den Haag.

Centraal Bureau voor de Statistiek ("), Volwasseneneducatie, Den Haag.

Centraal Plan Bureau (*), Centraal Economisch Plan, Den Haag.

Commission of the European Union, Task Force Human Resources, Education, Training and Youth (1993), Synoptic Tables. Information available in the twelve member states on Continuing Vocational Training, Brussels.

Dam, J.W. van, A. de Grip (1990), Technology Indicators: Population, Labour and Schooling. 1990 Report, ROA-R-1990/5E, Maastricht.

Dam, J.W. van, B.J.H. Lodder, G.W.M. Ramaekers (1991), Technology Indicators: Population, Labour and Schooling. 1991 Report, ROA-R-1991/9E, Maastricht.

Eurostat (*), Labour Force Survey, Luxembourg.

Grip, A. de (1987), Onderwijs en Arbeidsmarkt: Scholingsdiscrepanties, Amsterdam.

Grip, A. de, W.J. Nusselder (1989), Technology Indicators referring to Education and Labour, ROA-R-1989/4E, Maastricht.

Hoevenberg, J., A. de Grip (1993), Indicators of occupational employment in the European Union, ROA, Maastricht.

IMD (1993), The World Competitiveness Report.

International Labour Organisation ("), Yearbook of Labour Statistics, Geneva.

Kaiser, F., et al. (1992), Public Expenditure on Higher Education. A Comparative Study in the Member States of the European Community, Higher Education Policy Series 18, London.

Ministerie van Economische Zaken, Directie ATB (1990), METING 2. Indicatoren voor de technologische positiebepaling van Nederland. 
Ministerie van Onderwijs en Wetenschappen (1990), Skill-prognoses 1990, Den Haag.

Ministerie van Onderwijs en Wetenschappen (1993), Referentieraming 1993. Deel VIII Tijdreeksen uit de referentieraming 1992, Den Haag.

Minne, B. (1992), Technologie en economie: de Nederlanse positie, Research Memorandum no. 94, Centraal Planbureau (CPB), Den Haag.

Organisation for Economic Co-operation and Development $\left({ }^{*}\right)$, Labour Force Statistics, Paris.

Organisation for Economic Co-operation and Development/Centre for Educational Research and Innovation (*), Education at a Glance. OECD Indicators, Paris.

United Nations Educational Scientific and Cultural Organisation (*), Statistical Yearbook, Paris.

Willems, E.J.T.A., A. de Grip (1993), Toekomst in techniek? Waarde-oriëntatie, beeldvorming en keuze-intenties van jongeren, ROA-R-1993/7, Maastricht.

$\left({ }^{*}\right)=$ several annually updated versions used. 


\section{APPENDIX I: PREVIOUS STUDIES}

Grip, A. de, W.J. Nusselder (1989), Technology Indicators referring to Education and Labour, ROA-R-1989/4E, Maastricht.

Dam, J.W. van, A. de Grip (1990), Technology Indicators: Population, Labour and Schooling. 1990 Report, ROA-R-1990/5E, Maastricht.

Dam, J.W. van, B.J.H. Lodder, G.W.M. Ramaekers (1991), Technology Indicators: Population, Labour and Schooling. 1991 Report, ROA-R-1991/9E, Maastricht.

Dam, J.W. van, G.W.M. Ramaekers (1992), Technology Indicators: Population, Labour and Schooling. 1992 Report, ROA-R-1992/5E, Maastricht. 


\section{APPENDIX II: CLASSIFICATION OF INDUSTRIAL SECTORS}

\begin{tabular}{||l|l|l||}
\hline CPB sector & CORO sector & $\begin{array}{l}\text { Types of training } \\
\text { distinguished by the CBS }\end{array}$ \\
\hline $\begin{array}{l}\text { base metal industries, metal } \\
\text { production, } \\
\text { electrical industries }\end{array}$ & metals and electrical & $\begin{array}{l}\text { metal technologies I to IV, } \\
\text { automobiles, body-work, and } \\
\text { installation techniques }\end{array}$ \\
\hline $\begin{array}{l}\text { Wood and building materials and the } \\
\text { construction industry }\end{array}$ & building and wood & $\begin{array}{l}\text { construction technology, } \\
\text { woodwork, painting, road } \\
\text { construction and furniture } \\
\text { making }\end{array}$ \\
\hline foodstuffs industry & foodstuffs & foodstuffs technology \\
\hline chemical and rubber industries & process technologies & $\begin{array}{l}\text { process, measurement and } \\
\text { control technologies }\end{array}$ \\
\hline paper and printing industry & printing & printer's training \\
\hline transportation industry & transport & $\begin{array}{l}\text { harbour and transport } \\
\text { companies, nautical training, } \\
\text { passenger and goods } \\
\text { transport }\end{array}$ \\
\hline textiles, clothing, leather and \\
footwear industries & textiles and clothing & $\begin{array}{l}\text { textile \& clothing industry, } \\
\text { jewellery and engraving } \\
\text { techniques }\end{array}$ \\
\hline
\end{tabular}




\section{APPENDIX III: INFORMATION RECEIVED FROM THE NETWORK}

As in previous years, the most recent version of our report on technology indicators was mailed to the network of sixty statistical bureaus, research institutes, research sections of government departments and individual researchers in France, the United States, Great Britain, Germany and Sweden. It was accompanied by a request for information on education, training and employment that could be relevant in the framework of our research on technology indicators. We received reactions from the following institutes.

The Department of Labour and Educational Statistics of the Bureau of Statistics, Sweden, sent a fax with tables on the educational attainment in the years 1980-1990 of the Swedish population, labour force and unemployed, aged 16-64. The figures are divided by gender.

The sub-group for Educational Statistics sent a fax mentioning that they are working on the data collection for the network for 'Education and Labour Market Destination' in the INES project of OECD/CERI. At present they have submitted data for 1991 for publication and are also collecting data for development work.

The Central Statistical Office of the Government Statistical Service in the United Kingdom sent the 1992 edition of Government Statistics. A brief guide to sources.

The Department of Employment of the Resources and Strategy Directorate in the United Kingdom sent a letter which pointed to the previously mentioned Synoptic Tables of the European Commission, which contain data on continuing vocational training in the 12 EU member states. The Department of Employment pointed out that at present the data is not compiled on a comparable basis, although there are plans to rectify this in the future. According to the Department of Employment there are no other sources of comparable data that they are aware of.

The Universities Statistical Record in the United Kingdom pointed in their letter to their information on students in the older UK universities, ie. not to former polytechnics and colleges which attained university status in 1992 . Much of this data is published in their annual threevolume series of books entitled:

University Statistics; Volume 1: Students and Staff,

Volume 2: First destinations of University Graduates, and

Volume 3: Finance.

In addition, the Universities Statistical Record publishes another book called University Management Statistics and Performance Indicators in the UK. In their letter the Universities Statistical Record also provided the addresses of the (Government) Education Departments in the four UK countries for information specifically relating to school-leavers.

The Institut für Arbeitsmarkt- und Berufsforschung der Bundesanstalt für Arbeit (IAB) in Germany sent the following two publications:

Fischer, F. et al. (1993), Bestand und Bewegung im Bildungs- und Beschäftigungssystem der Bundesrepublik Deutschland. Ergebnisse der Bildungsgesamtrechnung für die alten und 
$-47-$

neuen Bundes/änder, Beiträge zur Arbeitsmarkt- und Berufsforschung, IAB, BeitrAB 170, Nürnberg.

Federal MOW (1992), Basic and Structural Data. Education Statistics for the Federal Republic of Germany. 1992/1993 Edition, Bonn.

The first of these contains data on recent developments with respect to education and the labour market in Germany. The second publication also includes an international comparison of the participation in various levels of initial education.

The US Department of Labor, Bureau of Labor Statistics, Office of Productivity and Technology, Division of Foreign Labor Statistics, airmailed the following documents which provided U.S. data on educational attainment and work force training:

1992 Educational Attainment Package of Tables;

How Workers get their Training: A 1992 update;

"Training to Qualify For Jobs and Improve Skills, 1992", Monthly Labor Review, September 1992;

"Job Training: Who Needs It and Where They Get It", Occupational Outlook Quarterly, Winter 92/93;

"Education and Training of American Workers", Paper prepared for the OECD National Experts Group on Training Statistics, June 1990.

In addition, the Division of Foreign Labor Statistics of the Office of Productivity and Technology of the Bureau of Labor Statistics referred our letter to the National Center for Education Statistics.

The Office of the Assistant Secretary for Educational Research and Improvement of the US Department of Education sent the following publication:

Alsalam, N., et al. (1993), The Condition of Education 1993, National Center for

Education Statistics, Washington, DC.

This provides detailed information on the status and progress of education in the United States. The publication also contains the following three internationally comparable indicators on education:

1. Percentage of the population who have completed secondary and higher education, by age, sex, and country: 1991 (source: OECD/CERI, International Indicators Project);

2. Distribution of proficiency scores of 9- and 13-year-olds on mathematics and science assessment, by country: 1991 (source: Educational Testing Service, International Assessment of Educational Progress, unpublished tabulations, 1992);

3. Average ability scores of 9- and 14-year-olds on reading literacy assessment, by country: School year 1991-92 (source: International Association for the Evaluation of Educational Achievement, Study of Reading Literacy, How in the world do students read?, 1992).

Unfortunately, the second indicator does not contain figures for the Netherlands. 


\section{APPENDIX IV: ADDITIONAL TABLES}

Table 1. Proportion of dual-system students in the total population between the ages of 15 and 24 ; 1983-90

\begin{tabular}{|c|c|c|c|c|c|c|c|c|}
\hline & $\begin{array}{r}1983 \\
\%\end{array}$ & $\begin{array}{r}1984 \\
\%\end{array}$ & $\begin{array}{r}1985 \\
\%\end{array}$ & $\begin{array}{r}1986 \\
\%\end{array}$ & $\begin{array}{r}1987 \\
\%\end{array}$ & $\begin{array}{r}1988 \\
\%\end{array}$ & $\begin{array}{r}1989 \\
\%\end{array}$ & $\begin{array}{r}1990 \\
\%\end{array}$ \\
\hline Netherlands & 2.5 & 2.4 & 2.3 & 2.3 & 2.3 & 1.9 & 1.7 & --- \\
\hline France & 2.6 & 2.6 & 2.5 & 2.4 & 2.6 & 2.8 & 2.9 & 8.4 \\
\hline Germany & 10.0 & 13.5 & 15.5 & 17.7 & 18.0 & 18.3 & 17.5 & 18.7 \\
\hline United Kingdom & 7.6 & 5.0 & 5.6 & 4.8 & 4.9 & 5.3 & 5.7 & 5.5 \\
\hline Italy & 0.5 & 0.6 & 0.5 & 0.6 & 0.6 & 0.6 & 0.8 & 0.8 \\
\hline Belgium & 2.3 & 1.9 & 1.8 & 1.9 & 1.6 & 1.3 & 1.5 & 2.8 \\
\hline Luxembourg & 5.8 & 6.3 & 7.0 & 6.1 & 5.7 & 5.1 & 4.8 & 5.1 \\
\hline Ireland & 2.8 & 2.2 & 2.5 & 2.0 & 1.9 & -- & 2.0 & 2.1 \\
\hline Denmark & 7.4 & 18.8 & 22.1 & 22.7 & 23.7 & 23.8 & 20.4 & 20.1 \\
\hline Greece & 0.3 & 0.3 & 0.4 & 0.5 & 0.3 & 0.3 & 0.3 & 0.4 \\
\hline
\end{tabular}

Source: Eurostat/ILO/ROA

Legend: $---=$ not available

Table 2. Indicator of the share of vocational education (second and third levels); 1975, 1980, 198590

\begin{tabular}{|c|c|c|c|c|c|c|c|c|}
\hline & $\begin{array}{r}1975 \% \\
\%\end{array}$ & $\begin{array}{r}1980 \% \\
\%\end{array}$ & $\begin{array}{r}1985 \% \\
\%\end{array}$ & $\begin{array}{l}1986 \% \\
\%\end{array}$ & $\begin{array}{r}1987 \% \\
\%\end{array}$ & $\begin{array}{r}1988 \text { \% } \\
\text { \% }\end{array}$ & 1989 & 1990 \\
\hline Netherlands & 51 & 53 & 56 & 57 & 57 & 58 & 59 & -- \\
\hline France & 35 & 36 & 36 & 41 & 38 & 39 & 40 & - \\
\hline Germany & 32 & 33 & 60 & 48 & 49 & 50 & 50 & -- \\
\hline United Kingdom & 16 & 18 & 24 & 26 & 27 & 28 & 30 & -- \\
\hline Sweden & 45 & 45 & 0 & 51 & 50 & 51 & 51 & 52 \\
\hline Austria & 25 & 33 & 41 & 43 & 43 & 44 & 45 & 45 \\
\hline Japan & 34 & 32 & 28 & 28 & 28 & 29 & 30 & -- \\
\hline
\end{tabular}

Source: UNESCO $(1985,1986,1987,1988,1991) / R O A$

Legend: -- = not available 
$-49-$

Table 4a. Participation in training (in the wider sense) as a percentage of the potential labour force between the ages of 15 and $49 ; 1983-91$

\begin{tabular}{|c|c|c|c|c|c|c|c|c|c|}
\hline & $\begin{array}{r}1983 \\
\%\end{array}$ & $\begin{array}{r}1984 \\
\%\end{array}$ & $\begin{array}{r}1985 \\
\%\end{array}$ & $\begin{array}{r}1986 \\
\%\end{array}$ & $\begin{array}{r}1987 \\
\%\end{array}$ & $\begin{array}{r}1988 \\
\%\end{array}$ & $\begin{array}{r}1989 \\
\%\end{array}$ & $\begin{array}{r}1990 \\
\%\end{array}$ & $\begin{array}{r}1991 \\
\%\end{array}$ \\
\hline Netherlands & 5 & -- & 5 & - & 6 & 7 & 7 & -- & -- \\
\hline Germany & -- & 6 & 7 & 9 & 8 & 9 & 8 & 9 & 19 \\
\hline United Kingdom & 7 & 7 & 7 & 7 & 8 & 9 & 10 & 10 & 11 \\
\hline Italy & 1 & 1 & 1 & 1 & 2 & 2 & 2 & 2 & 2 \\
\hline Belgium & 2 & 2 & 2 & 2 & 2 & $\overline{1}$ & 2 & 2 & 2 \\
\hline Luxembourg & 3 & 3 & 3 & 3 & 3 & 3 & 2 & 2 & 3 \\
\hline Ireland & 3 & 3 & 3 & 3 & 3 & -- & 3 & 4 & 3 \\
\hline Denmark & 10 & 13 & 15 & 16 & 16 & 14 & 10 & 11 & 12 \\
\hline Greece & 1 & 1 & 1 & 1 & 1 & 1 & 1 & 1 & 1 \\
\hline
\end{tabular}

Source: Eurostat/ROA

Legend: $---=$ not available

Table 4b. Participation in training (in the narrow sense) as a percentage of the potential labour force between the ages of 15 and $49 ; 1983-91$

\begin{tabular}{|c|c|c|c|c|c|c|c|c|c|}
\hline & $\begin{array}{r}1983 \\
\%\end{array}$ & $\begin{array}{r}1984 \\
\%\end{array}$ & $\begin{array}{r}1985 \\
\%\end{array}$ & $\begin{array}{r}1986 \\
\%\end{array}$ & $\begin{array}{r}1987 \\
\%\end{array}$ & $\begin{array}{r}1988 \\
\%\end{array}$ & $\begin{array}{r}1989 \\
\%\end{array}$ & $\begin{array}{r}1990 \\
\%\end{array}$ & $\begin{array}{r}1991 \\
\%\end{array}$ \\
\hline Netherlands & 2 & -- & 2 & - & 2 & 2 & 2 & --- & -- \\
\hline Germany & 0 & 0 & 1 & 1 & 1 & $\overline{1}$ & $\overline{1}$ & 1 & 1 \\
\hline United Kingdom & 1 & 2 & 2 & 2 & 2 & 3 & 3 & 3 & 3 \\
\hline Italy & 0 & 0 & 0 & 0 & 0 & 0 & 0 & 0 & 1 \\
\hline Belgium & 1 & 1 & 1 & 1 & 1 & 0 & 1 & 0 & 1 \\
\hline Luxembourg & 1 & 0 & 0 & $i$ & 1 & 1 & $i$ & 1 & 1 \\
\hline Ireland & 2 & 2 & 2 & 2 & 2 & --- & 2 & 3 & 2 \\
\hline Denmark & 2 & 2 & 3 & 4 & 4 & 4 & 3 & 3 & 3 \\
\hline Greece & 0 & 0 & 0 & 0 & 0 & 0 & 0 & 0 & 0 \\
\hline
\end{tabular}

Source: Eurostat/ROA

Legend: --- = not available 
$-50-$

Table 6a. Percentage share of the labour volume contributed by employees with primary apprenticeship agreements, by industrial sectors; $1975,1980,1985-92$

\begin{tabular}{lrrrrrrrrrr}
\hline Sector & $\begin{array}{r}1975 \\
\%\end{array}$ & $\begin{array}{r}1980 \\
\%\end{array}$ & $\begin{array}{r}1985 \\
\%\end{array}$ & $\begin{array}{r}1986 \\
\%\end{array}$ & $\begin{array}{r}1987 \\
\%\end{array}$ & $\begin{array}{r}1988 \\
\%\end{array}$ & $\begin{array}{r}1989 \\
\%\end{array}$ & $\begin{array}{r}1990 \\
\%\end{array}$ & $\begin{array}{r}1991 \\
\%\end{array}$ & $\begin{array}{r}1992 \\
\%\end{array}$ \\
\hline & & & & & & & & & & \\
Metals and electrical & 3.7 & 5.1 & 5.0 & 6.2 & 7.0 & 7.0 & 6.9 & 6.6 & 4.6 & 4.6 \\
Building and wood & 0.9 & 1.9 & 1.9 & 2.2 & 2.3 & 2.4 & 2.5 & 2.8 & 2.6 & 2.5 \\
Foodstuffs & 1.9 & 2.9 & 3.4 & 3.7 & 4.0 & 4.4 & 4.2 & 4.1 & 4.5 & 4.5 \\
Process technologies & 0.5 & 0.9 & 1.4 & 2.2 & 2.0 & 1.8 & 1.9 & 2.0 & 1.9 & 1.9 \\
Printing & 0.7 & 1.6 & 1.2 & 1.5 & 1.8 & 1.8 & 2.0 & 2.0 & 1.6 & 1.2 \\
Transport & 0.2 & 0.3 & 0.5 & 0.6 & 0.6 & 0.7 & 3.7 & 4.0 & 3.6 & 4.4 \\
Textiles and clothing & 0.7 & 0.9 & 1.8 & 2.2 & 2.1 & 2.2 & 1.9 & 2.0 & 0.8 & 0.7 \\
\hline
\end{tabular}

Source: $\mathrm{CBS} / \mathrm{CPB} / \mathrm{ROA}$

Table 6b. Percentage share of the labour volume contributed by employees with secondary level apprenticeship agreements, by industrial sectors; 1975, 1980, 1985-92

\begin{tabular}{lrrrrrrrrrr}
\hline Sector & $\begin{array}{r}1975 \\
\%\end{array}$ & $\begin{array}{r}1980 \\
\%\end{array}$ & $\begin{array}{r}1985 \\
\%\end{array}$ & $\begin{array}{r}1986 \\
\%\end{array}$ & $\begin{array}{r}1987 \\
\%\end{array}$ & $\begin{array}{r}1988 \\
\%\end{array}$ & $\begin{array}{r}1989 \\
\%\end{array}$ & $\begin{array}{r}1990 \\
\%\end{array}$ & $\begin{array}{r}1991 \\
\%\end{array}$ & $\begin{array}{r}1992 \\
\%\end{array}$ \\
\hline & & & & & & & & & & \\
Metals and electrical & 0.6 & 1.3 & 1.4 & 1.8 & 2.2 & 2.6 & 3.2 & 3.6 & 2.9 & 3.0 \\
Building and wood & 0.4 & 0.4 & 0.6 & 0.7 & 0.8 & 0.9 & 1.0 & 1.1 & 1.0 & 1.1 \\
Foodstuffs & 0.6 & 1.4 & 1.3 & 1.6 & 1.8 & 2.0 & 2.2 & 2.4 & 2.8 & 2.8 \\
Process technologies & 0.0 & 0.1 & 0.0 & 0.1 & 0.6 & 1.1 & 1.3 & 1.6 & 1.6 & 1.8 \\
Printing & 0.2 & 0.3 & 0.2 & 0.3 & 0.6 & 0.6 & 0.7 & 0.7 & 0.7 & 0.6 \\
Transport & 0.0 & 0.0 & 0.0 & 0.0 & 0.0 & 0.0 & 0.4 & 0.3 & 0.3 & 0.6 \\
Textiles and clothing & 0.0 & 0.0 & 0.2 & 0.1 & 0.1 & 0.2 & 0.2 & 0.2 & 0.1 & 0.1 \\
\hline
\end{tabular}

Source: $C B S / C P B / R O A$ 